*ak RMIS View/Frint Document Cover Sheet tow

This document was retrieved from the Documentation and Records Manaqement (DRM) ISEARCH System. It is intended for Information only and may not be the most recent or updated version. Contact a Document Service Center (see Hanford Info for locations) if you need additional retrieval information.

Accession \#: D196023630

Document \#: SD-WM-ATR-104

Title/Desc:

BREATHING AIR TRAILER ACCEPTANCE TEST REPORT

Pages: 45 
$\checkmark l$

FE $1 \% 995$ ENGINEERING DATA TRANSMITTAL

Page 1 of 1

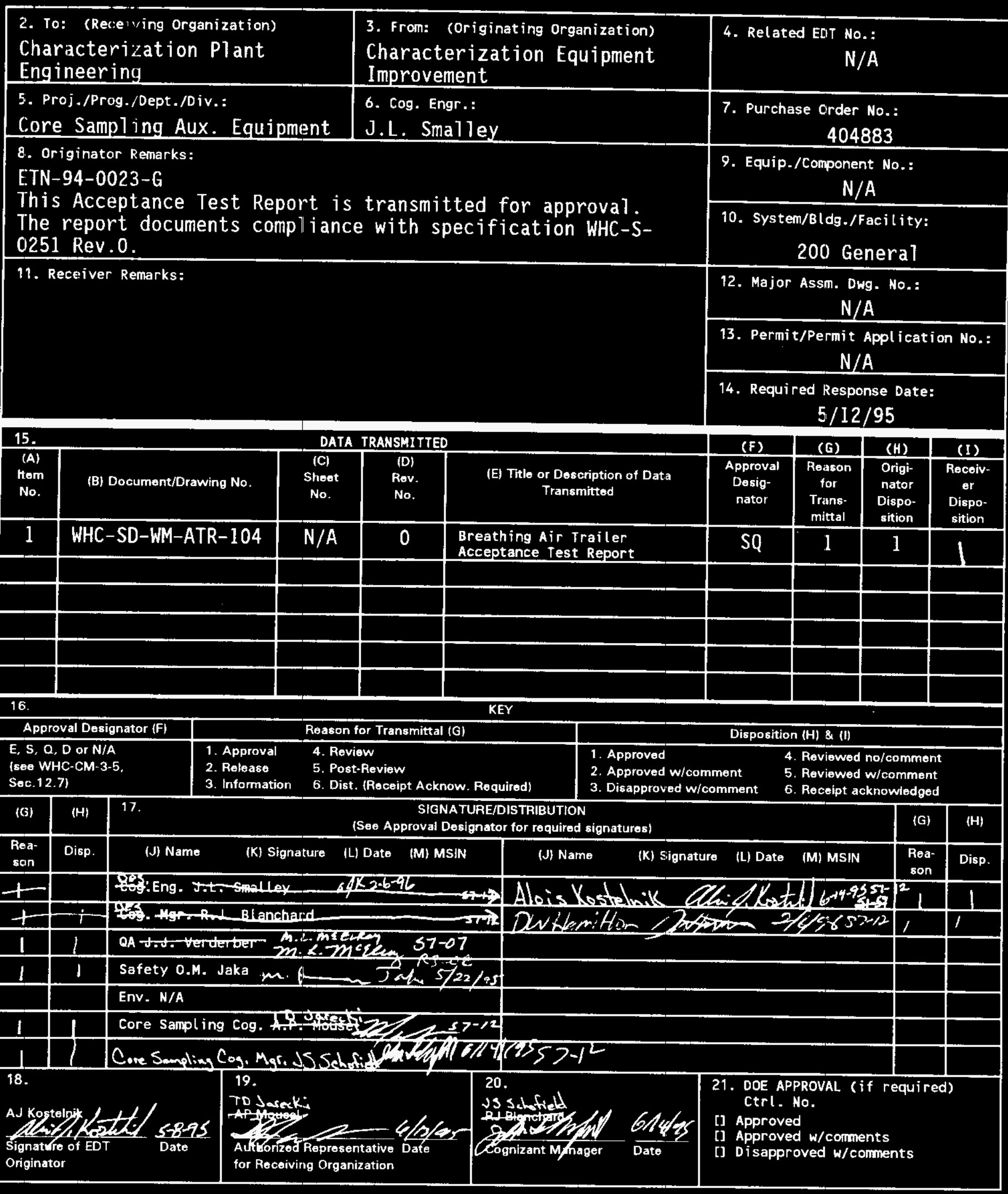

BD-7400-172-2 (04/94) GEF097 


\title{
BREATHING AIR TRAILER ACCEPTANCE TEST REPORT
}

\author{
ALOIS J. KOSTELNIK \\ WESTINGHOUSE HANFORD COMPANY, Richland, WA 99352 \\ U.S. Department of Energy Contract DE-AC06-87RL10930 \\ EDT/ECN: 612069 \\ UC: 2070 \\ Org Code: 75230 \\ Charge Code: N4H2B \\ B\&R Code: $243 / 20074$ Total Pages: 43
}

Key Words: ETN-94-0023-G, Core Sampling, Breathing Air, Specification WHC-S-0251, Trailer, American Bristol, Air Compressor, Purchase Order 404883, Core Sampling Ancillary Equipment, Portable Breathing Air Supply

Abstract: This Acceptance Test Report documents compliance with the requirements of specification WHC-S-0251, Rev.0 and ECNs 613530 and 606113. The equipment was tested according to WHC-SD-WM-ATP-104. The equipment tested is a Breathing Air Supply Trailer purchased as a design and fabrication procurement activity. The ATP was written by the Seller and was performed by the Seller with representatives of the Westinghouse Hanford Company witnessing portions of the test at the Seller's location.

TRADEMARK DISCLAIMER. Reference herein to any specific commercial product, process, or service by trade name, trademark, manufacturer, or otherwise, does not necessarily constitute or imply its endorsement, recommendation, or favoring by the United States Government or any agency thereof or its contractors or subcontractors.

Printed in the United States of America. To obtain copies of this docunent, contact: WHC/BCS Document Control Services, P.O. Box 1970, Mailstop H6-08, Richland WA 99352, Phone (509) 372-2420;
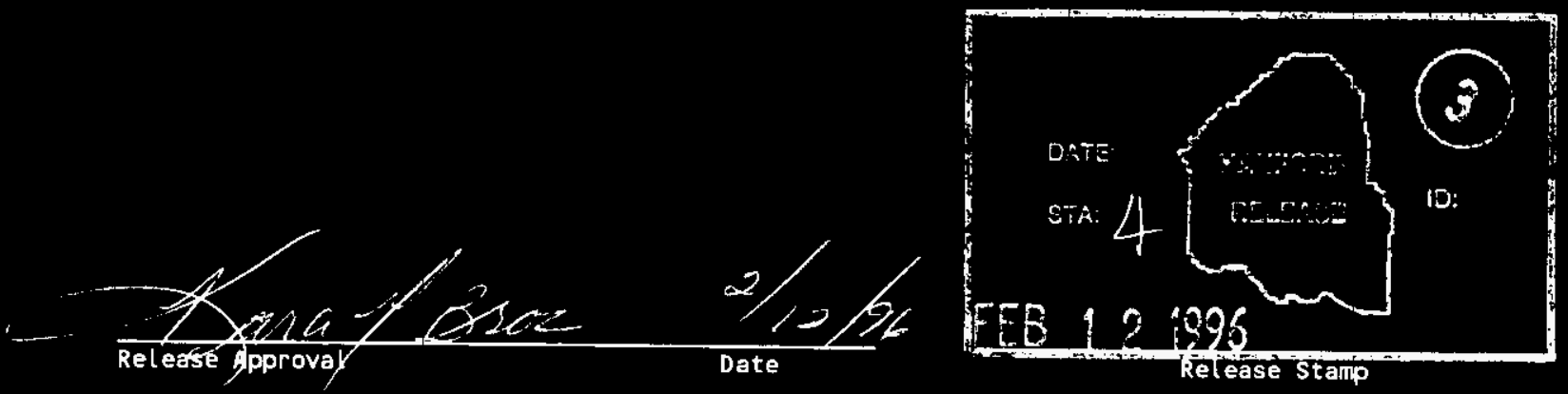

\section{Approved for Public Release}


WHC-SD-WM-ATR-104

Rev. 0

Page 2

\section{TABLE OF CONTENTS}

SUMMARY

Page 3

APPENDIX A (ATP results for Breathing Air Trailer SN 9R940601-8)

Page A1

APPENDIX B (ATP results for Breathing Air Trailer SN 9R90602-9)

Page B1

APPEYDIX C (NEC Inspection Resules)

Page Cl

APPENDIX D (Receipt inspection Report)

Page D1 


\section{SUMNARY}

The test was performed at American Bristol Inc. in Harbor City, CA. The Breathing Air Trailers were inspected by WHC for general operability requirements, labeling, suspect fasteners, and finish. A WHC electrical inspector performed an inspection for compliance with the National Electric code.

The equipment was unsuccessful at achieving the specified operational requirements while WHC representatives were present. The major discrepancies which were identified while WHC personnel were present are as follows. The reserve air capacity was limited by an undersized pressure regulator valve which caused a flow restriction. The air dryer was not able to achieve the dewpoint requirements because it had not been operating long enough to dry the desiccant. Air samples could not be taken because the dewpoint was too high and the air would not have met the Grade D breathing air requirements. Other portions of the testing could not be completed while WHC was present due to time limitations.

American Bristol Inc. completed the Acceptance Test without WHC representatives present. An air sample was taken from the system and sent to an independent $1 \mathrm{ab}$ for testing. The air sample meets the requirements for Grade D air. The system will be sampled and tested on site by the Hanford Environmental Health Foundation for Grade D air quality prior to use. The reserve air system was redesigned with a larger pressure regulator which does not restrict the flow.

The Acceptance Test results, including the Air Quality Report from Trace Analytics, for Breathing Air Trailer SN 9R940601-8 are in Appendix A. The Acceptance Test results for Breathing Air Trailer SN 9R90602-9 are in Appendix B. The NEC Inspection Result Memo for both units is in Appendix C. The Receipt Inspection Report is in Appendix D. 
2. To: (Receiving Organization) Core Sampling

5. Proj./Prog./Dept./Div.:

Core Sampling Aux. Equipment

8. Originator Renarks:

ETN-94-0023-G

This Acceptance Test Procedure is transmitted for approval. The procedure was prepared by the Seller and will be performed at the Sellers location. It will show compliance with specification WHC-S-0251 Rev. 0 .

\section{Receiver Remarks:}

3. From: (Originating Organization) Characterization Equipment 6. Cog. Engr.:

J.L. Smalley
Page 1 of

r 608067

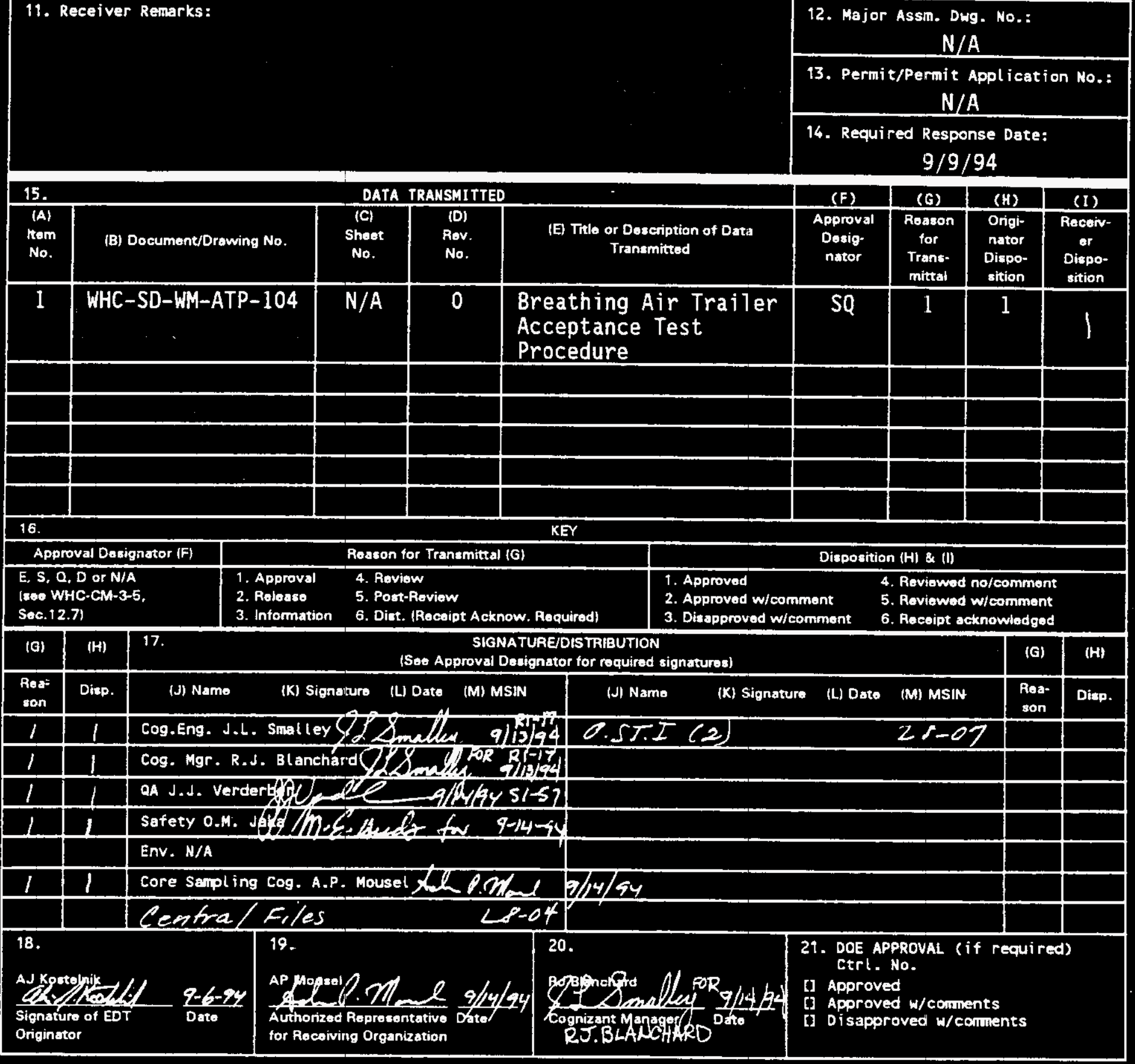

BD-7400-172-2(04/94) GEF097 


\section{RELEASE AUTHORIZATION}

Document Number: WHC-SD-WM-ATP-104, REVISION 0

Document Title: Breathing Air Trailer Acceptance Test Procedure

Release Date: $\quad 09 / 14 / 94$

This document was reviewed following the procedures described in WHC-CM-3-4 and is:

APPROVED FOR PUBLIC RELEASE

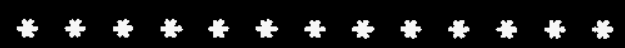

WHC Information Release Administration Specialist:

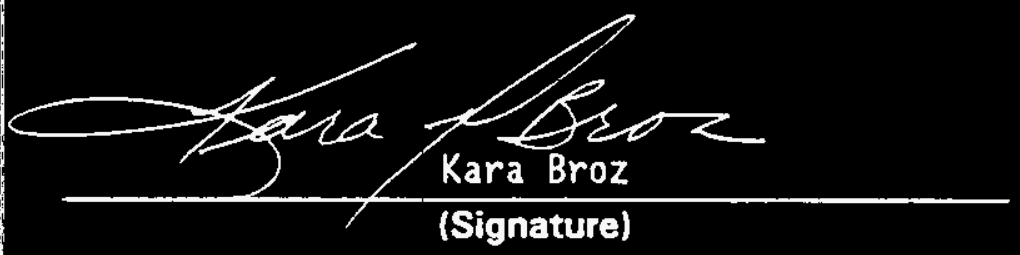

$\frac{09 / 14 / 94}{\text { (Date) }}$


2. Title

Breathing Air Trajler Acceptance Test Procedure

5. Key Words

ETN-94-0023-G, Core Sampling, Breathing Air, Specification WHC-S-0251, Trailer, American Bristol, Air Compressor, Purchase Order 404883, Core Sampling Auxiliary Equtpment, Portabte....... Breathing Air Supply

7. abstract $\frac{1 / 1+/ 4 \text { PUBLIC RELEASE }}{\text { A }}$

This Acceptance Test Procedure (ATP) will document compliance with the requirements of WHC-S-0251 Rev. 0 and ECNs 613530 and 606113. The equipment being tested is a Breathing Air Supply Trailer purchased as a Design and Fabrication procurement activity. The ATP was written by the Seller and will be performed by the Seller with representatives of the Westinghouse Hanford Company witnessing the test at the Seller's location.

8. PuReose AND USE OF DOCUMENT - This docunent was prepared for dSe with in the U.S. Department of Energy and its contractors. $T$ is to be used only to perform, direct, or integrater work under U.S. Department of Energy contracts. This docupent is not approved for publ ic release untivi reviewed.

PATENT status - This document rody, since it is transmitted in advance of patent clearance its made axajlable in confidence solely for use in performases of work work contracts with the U.S. Department of Energy. This document is not to be published nor its contents othrorwise disseminated or used for purposes ather than specified dbove before patent approval for such release or use has begarsecured, upon request, from the Patent Counsel, U.S. Department Of Energy Field office, Richtiand, WA.

DISCLAIMER - This report was prepared as an account of work sponsored by an agency of the United States Goverment. Neither the United States Government nor any agency thereof, nor any of their employees, nor any of their contractors, subcontractors or their employees, makes any warranty, express or implied, or assumes any legal liability or responsibil ity for the accuracy, completeness, or any third party's use or the results of such use of any information, apparatus, product, or process disclosed, or represents that its use would not infringe privately owned rights. Reference herein to any specific commercial product, process, or service by trade name, trademark, manufacturer, or otherwise, does not necessarily constitute or imply its endorsenent, recomendation, or favoring by the United States Government or any agency thereof or its contractors or subcontractors. The views and opinions of authors expressed herein do not necessarily state or reflect those of the United States Government or arly agency thereof.

10.

RELEASE STAMP

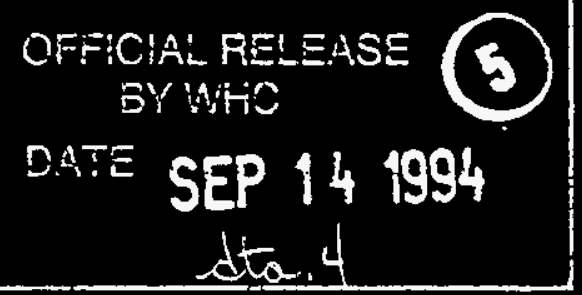

9. Impact Level SQ 


\section{TABLE OF CONTENTS}

TITLE PAGE

1.0 SCOPE

2.0 SEqUENCE

3.0 VISUAL INSPECTION

4.0 OPERATIONAL INSPECTIONS

5.0 POST OPERATIONAL CHECKOUTS

ACCEPTANCE TEST PROCEDURE MORK SHEETS

TEST EXCEPTIONS
Page 3

Page 4

Page 4

Page 4

Page 4

Page 6

Page 8

Page 11 


\author{
ACCEPTANCE TEST PROCBDURE \\ MOBILE BREATHING AIR TRAILER \\ MODEL 5014-0001
}
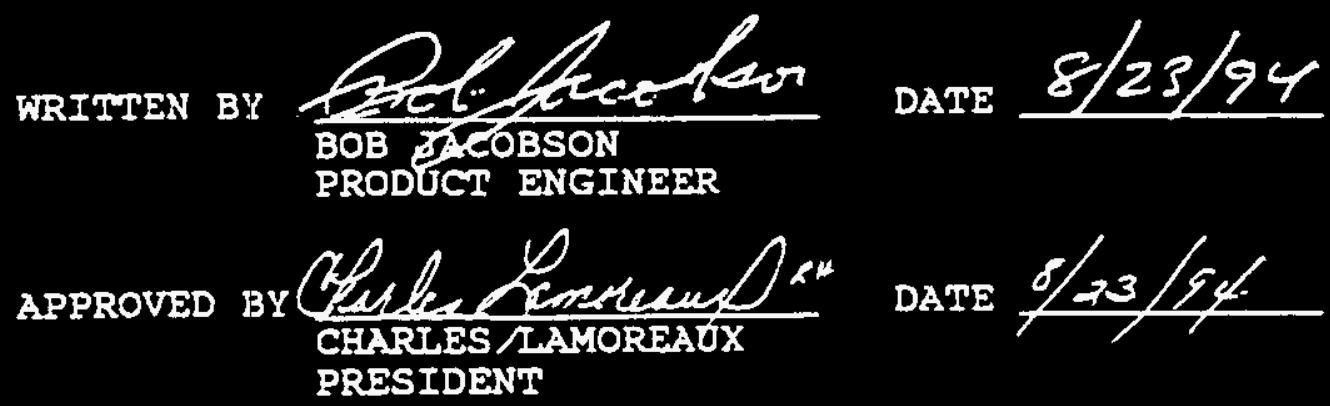
1.0 SCOPE

This test procedure is to verify that the American Bristol Industries, Inc., Yodel 5014-0001 low pressure Mobile Breathing Air Trailer, meets or exceeds the requirements of the Westinghouse Hanford specification. (WHC-S-0251)

2.0 SBQUENCE

ABI will complete the following tests in the order deemed best by ABI personnel.

3.0 VISUAL INSPECTION

Visually inspect the unit to verify that it complies with the reguirements of the purchase specification. Record the pertinent data on the data sheets provided.

3.1 Visually inspect the unit for:

3.1.1 Damage.

3.1 .2 Cleanliness; no weld spatter; no foreign materials.

3.1.3 Uniformity of finish: no bubbles, chips, scratches.

3.1.4 All wiring and plumbing secured in place.

3.1.5 All wiring undamaged, connections tight.

3.1.6 Al1 wires tagged.

3.1.7 AlI major components tagged with manufacturers' nameplates.

3.1.8 ABI nameplate stamped \& installed.

3.1.9 VIN number stamped on unit.

3.1.10 All ground wires properly connected.

3.1.11 Verify that lunette eye ID is 2.75 inches minimum.

4.0 OPERATIONAL INSPECTIONS

4.1 Break-in Inspections

4.1.1 Verify incoming power at the magnetic starter.

4.1.2 Verify proper compressor rotation before starting break-in procedures. 
4.1.3 Operate each unit in accordance with the break-in schedule table on the data sheets. Record the start up current and the running current.

4.1.4 During break-in, carefully observe the unit for any evidence of excessive vibration, excessive heat, strange noises, odors, etc., loose components, interferences between components and leakages. Correct as required.

\subsection{Leak Test}

4.2.1 Upon completion of the break-in test, shut the system down with the rated pressure trapped in the system. Bubble test all fittings, joints, valve stems, burst discs, etc. for any evidence of leakage. Correct as required. (Working pressure 80-125 psig)

4.2.2 Attach hose and manifold to system and pressurize to working pressure. Bubble test all joints for any evidence of leakage. Correct as required.

\subsection{Relief Valve Test}

4.3.1 With the unit running, activate all relief valves to verify each valve will flow.

4.3.2 Verify each relief valve reseats and does not leak.

\subsection{Condensate Drain Test}

4.4.1 With the unit running, verify that there are no leaks in the automatic condensate drain system by immersing the drain tube in water and observe any leakage. correct as required.

4.4.2 Record the time between dump cycles and the duration of the dump.

4.4.3 Allow the system to shut off automatically. Verify that the dump valves open and that the compressor continues to run in its cool down mode. Record the time of the cool down run.

4.4.4 Close the interstage and filter manual drain valves. Bring the system up to pressure and shut off. Observe for leakage by immersing the drain tube in water.

\subsection{Compressor Operational Test}

4.5.1 Measure compressor output per standard practice sheet or by use of a pressure gauge and a flow meter. Record the data. 
4.5.2 Record the rotational speed of the compressor.

4.5.3 Record the temperature of the air receiver at its discharge while flowing air at rated pressure and flow. 4.5.4 Take an air sample in accordance with the sampling company's procedures and ship the sample for analysis.

4.5.5 Shut down the system and allow it to cool to room temperature. After it has cooled down, run it again for 5 minutes with the intercooler drains open to remove any additional condensation.

4.6 Monitor / Controller Operational Test

4.6.1 Verify that the Automatic start/stop function operates.

4.6.2 Verify that the Manual start/stop function operates.

4.6.3 Verify that the high temperature stop operates properly.

4.6.4 Verify that the low oil stop operates properly.

4.6.5 Verify that the high co portion of the monitor operates in accordance with its manual. (Set at 10ppm and 25ppm)

4.6.6 Verify that the high dew point portion of the monitor operates in accordance with its manual.

4.6.7 Verify the low pressure sensor actuates the reserve air supply. (and there is adequate supply for 5 minutes.)

4.6.8 Verify that the audio/visual alarms function whenever any of the above safety features are actuated.

4.7 Filters, Dryer, and Chiller Operation

4.7.1 Verify that the filters have the correct elements installed.

4.7.2 Verify that the swing dryer has the correct chemicals installed and that it functions in accordance with its operating manual.

4.7.3 Verify that the chiller functions in accordance with its operating manual.

5.0 POST OPDRATIONAI, CLIXCKOUTS

5.1 Verify all tires are at recominended inflation pressure

5.2 Set the parking brake, Verify that the parking brakes hold by pushing / puliing the unit. The wheels should skid instead of rolling. Adjust as required. 
5.3 Verify the surge brakes actuate by towing the unit and applying the brakes. The unit should not push the tow vehicle nor fish tail. Adjust as required.

5.4

Verify that the compressor oil level is full.

5.5

Verify that the surge brake system is full of brake fluid.

5.6

Record final hour meter reading.

5.7

Verify that all components are securely mounted.

5.8

Verify that the cable reel fully extends and retracts.

5.9

Verify that the main landing jack and leveling jacks extend and retract and that the leveling jacks pivot and lock out of the way.

5.10

Verify that all DOT lights are functional.

5.11

Verify that the brake lights, back up lights and turn signals are functional. 
ACCEPTANCE TEST PROCEDURE WORK SHEE

Order: 11234

Configuration: OPERATOR:
CUSTOMER:

\section{Soria :92940E $01-8$}

$\therefore P$ HAR I

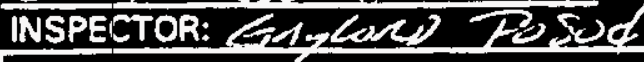

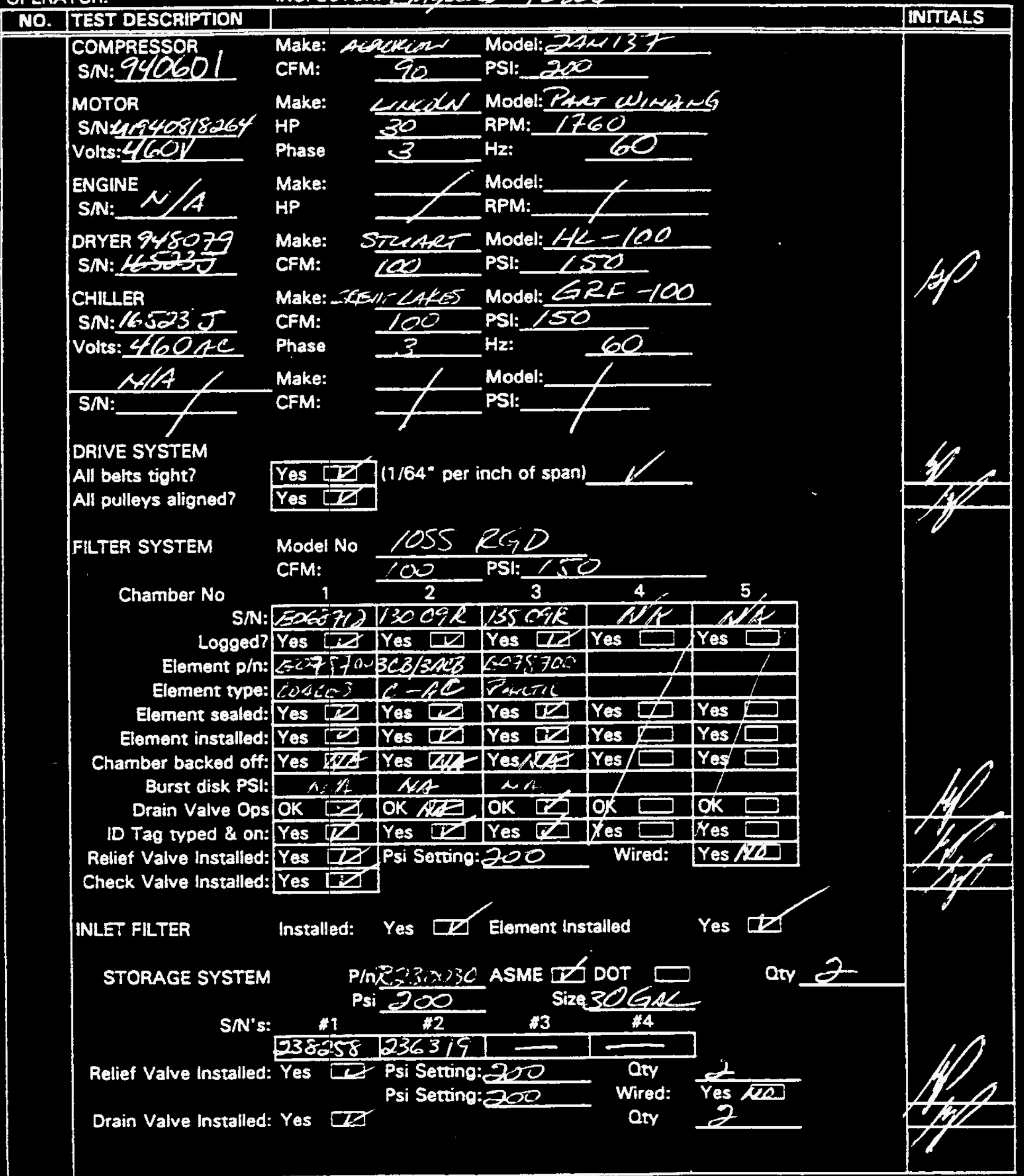

900\%5

77 
Order $* 2 / 234$

Model $50 / 4-0001$ Configurction:

OPERATOR:

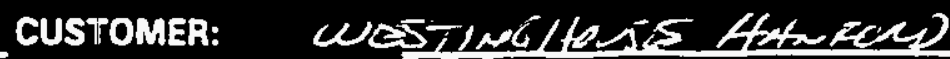

\section{Serial : $92942601-8$} $\angle P H A C D 2 \mu / 37$

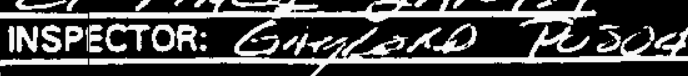

\section{NO. TTEST DESCAIPTION \\ 3.0. VISUAL EXAMINATION}

7

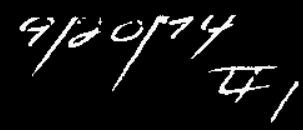

3.1.1 No damage:

3.1.2 Clean, no weld spatter, foreign material:

3.1.3 Finish : Uniform, no bubbles, chips nor scratches

3.1.4 Wiring $\&$ plumbing secured:

3.1.5 No damage to wires, All connections tight $\&$ in place:

3.1.6 All wires tagged

3.1.7 All major components tagged with mfg'r's nameplates:

3.1.8 ABI nameplate stamped \& installed:

3.1.9 VIN number stamped on unit

No: 149LM77292AO79112

3.1.10 All wires grounded:

3.1.11 Lunette eye ID $>2.75$ inches 3 ,

4.0. OPERATIONAL INSPECTIONS AND TESTS

4.1 Break in Inspections

4.1.1 Votrage: *4601230IVAC

4.1.2 Proper Rotation: (CCW)

461

Current:

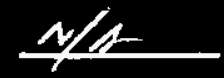

TMITLLS

4.1.3 Operate each unit according to the following table and record start up and running current

\begin{tabular}{|c|c|c|c|c|}
\hline Motor & Engine & Speed & Load & Current \\
\hline $30 \mathrm{Min}$ & & Rated & Low & 220 \\
\hline 3-4 Hrs. & & Rated & Rated & \\
\hline & 15-30 Min & Fast Idle & Min & -4 \\
\hline & $1 \mathrm{Hr}$ & Rated & Light-Med & 1772 \\
\hline & $2.3 \mathrm{Hrs}$ & Rated & Rated & $y$ \\
\hline \multirow{4}{*}{\multicolumn{2}{|c|}{$\begin{array}{l}\text { Excessive heat } \\
\text { Strange noises } \\
\text { Strange odors } \\
\text { Other } \\
\text { Vibration }\end{array}$}} & \multicolumn{3}{|l|}{$\infty$} \\
\hline & & \multicolumn{3}{|l|}{ NONAS } \\
\hline & & \multicolumn{3}{|l|}{ Lewes } \\
\hline & & \multicolumn{3}{|l|}{$\alpha$} \\
\hline
\end{tabular}

4.2 Leak Test

4.2.1 No leaks in system

Busile Lanks owLy

4.2.2 No leaks in hoses

4.3 Relief Valve Test

4.3.1 Activate all relief valves

4.3.2 All relief valves reseat

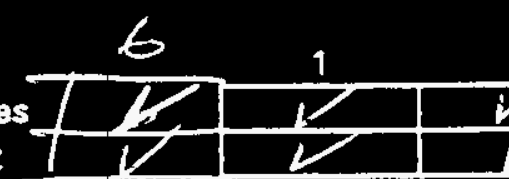

4.4 Condensate Drain Test

4.4.1 Does not leak during operation

4.4.2 Time between dump cycles
4.4.3 Veriy dumps open during Cool Down \& Purge

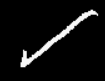

4.4.4 Does ich leak after shut off

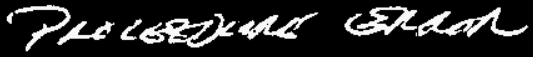
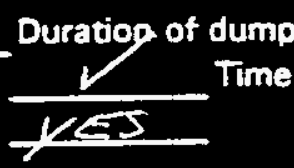

Time

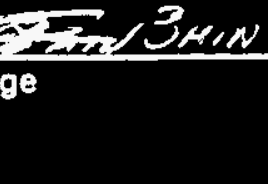

7

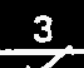

3

4
Current

$\frac{38}{38}$
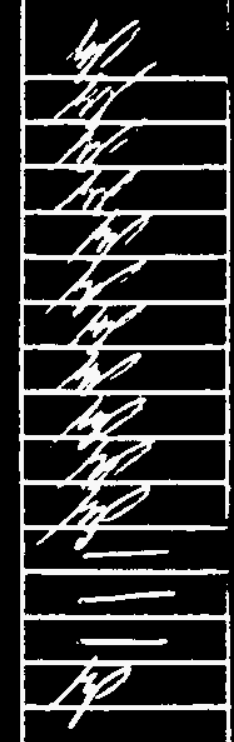

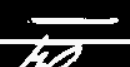
4 (1) 


\section{Order * CUSTOMER: Sorial * CUETTingtexs \\ Model :SO/4-DDOL Configuration: OPERATOR: $\angle M$ MACI 2ANI3Z NO. TTEST DESCRIPTION INSPECTOR:}

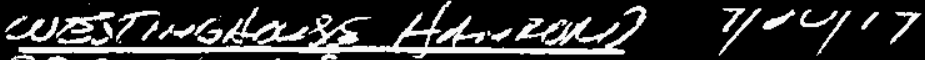

\begin{tabular}{|c|l|}
\hline 4.5 & Compressor Operationa \\
4.5 .1 & Measure Output \\
& \\
4.5 .2 & Compressor \\
4.5 .3 & Temperature \\
4.5 .4 & Take Air Sample \\
&
\end{tabular}

4.5.5 After cool down to room temp run for 5 minutes with drains open

4.6 Monitor / Controller Operational Test

4.6.1 Auto start / stop

4.6.2 Manual start / stop

4.6.3 High temperature stop $350-2$

4.6.4 Low oil stop

4.6.5 Hi CO operation

$10 \mathrm{ppm}$. $\frac{M / 4}{\text { FAB minures to fill a }}{ }^{\text {psi }} 82$ scFi SCFM @ $@ 100$ PSI

4.6.6 Hi dew point operation

4.6.7. Low air pressure sensor operation and 5 minutes reserve air available.

4.6.8 Audio / Visual alarm functions with all of the above

4.7 Filters, Dryer and Chiller Operation

4.7.1 Correct fitter elements installed

4.7.3 Chiller operates properiy

5.0. POST OPERATIONAL CHECKOUTS

5.1 Tire pressure

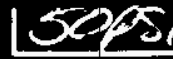

25 ppmero Sonece Ausitable

5.2 Parking brake functions properly

5.3 Surge brake functions properly

5.4 Compressor oil level FULL.

5.5 Surge brake system oil level

5.6 Hour Meter Reading

FULL

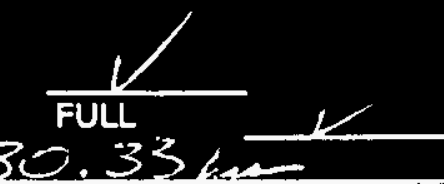

5.7 All components securely mounted. No loose bolts, nuts, pins, etc..

5.8 Cable reel pays out and picks up cable

5.9 Main landing jack extends \& retracts

Leveling jacks extend, retract \& pivot \& lock out of the way

5.10. DOT lights are functional

5.11 Brake lights, turn signals, \& backup lights are functional

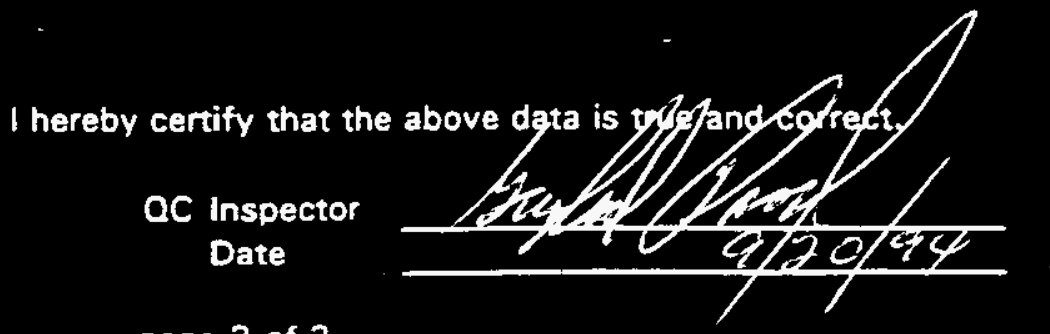

page 3 of 3 


\section{TEST EXCEPTIONS}

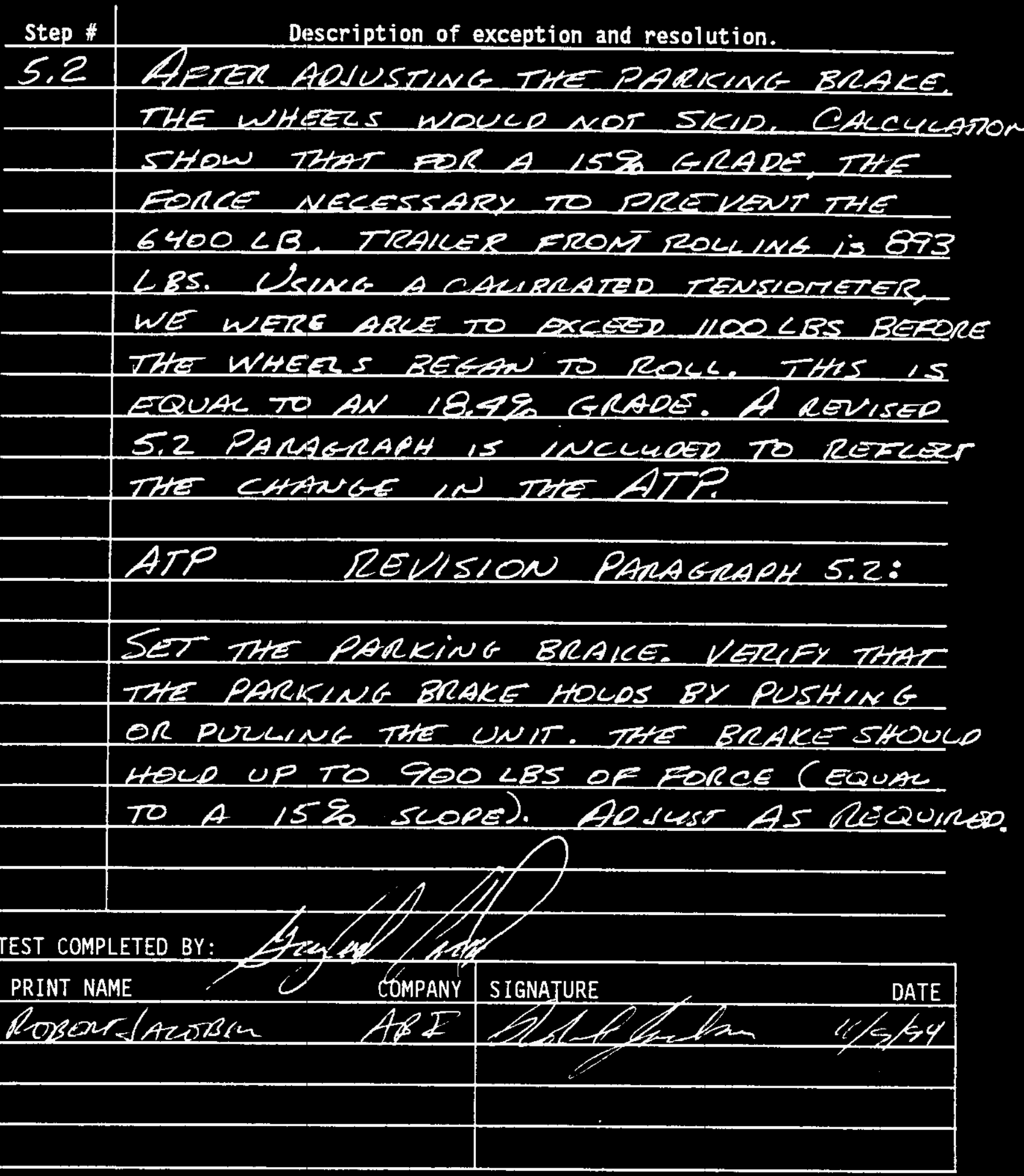


DUE: $10-31-94$

WHC-SD-WM-ATR-104

Rev. 0

Appendix A-14 of A-15

DATE $10-31-94$

REQUEST FOR FILTER TAGS

s.0. 112234

74

CARTRIDGE:

) $=007712$

2) $3 C B-3 / 3 A C B$

3) $E 0 \mp 8700$

4) $=078700$

MODEL:

1OSS-RGD

wop. 250

PSI

SERIAL:

$$
\frac{134-199 R}{2 \frac{130-09 R}{135-\cos R}}
$$

Pron 100

CF

FRESH AR -

'suse

MODEL LP MACE

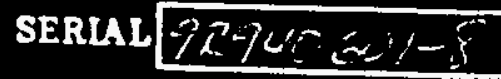

PS il 100 CPU 90

RPM $\longdiv { 5 6 0 }$

RP 30

POKER $780 \mathrm{~V}$ AC SPA

Los Angeles, cantoris

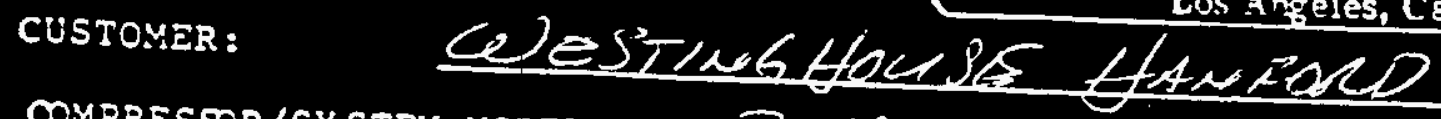

COMPRESSOR/SY STEM MODEL NO: $\angle P$ PACT SOI4-OEO/ COMPRESSOR UNIT S/N:(1)

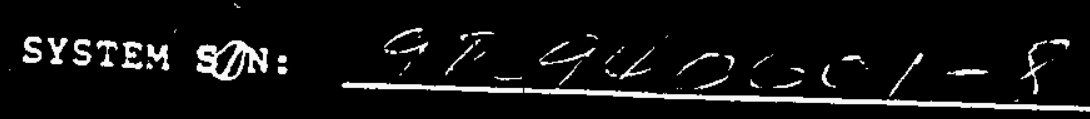

uniat: $\quad 2 \leq 2 \leq$

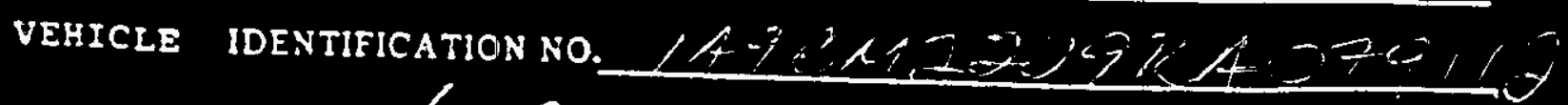

REQUESTED BY: 
P.O. Box 160850 - Austin, TX 78716 - 800-AFP-1024 - 512-328-4076 - FAX 512-328-4122

Customer: 123

American Bristol Ind.

Mr. Chuck Lamoreaux

1600 W 240th St.

Harbor City, CA 90710
Report No.: 94-3848

Date Analyzed: October 27, 1994

Sampled By: K. Lamoreaux

Date Sampled: October 26, 1994

Air Source ID: L. P. Trailer \# $1 \mathrm{~S} / \mathrm{N}$

1A9CM2229RA079112

\section{Sampled for Westinghouse Hanford}

COMPRESSED AIR ANALYTICAL RESULtS

\begin{tabular}{|c|c|c|c|}
\hline $\begin{array}{c}\text { LIMITING } \\
\text { CHARACTERISTIC }\end{array}$ & $\begin{array}{l}\text { SOURCE AIR } \\
\text { RESULTS }\end{array}$ & $\begin{array}{l}\text { AMBIENT AIA } \\
\text { RESULTS }\end{array}$ & $\begin{array}{l}\text { CGA Grade D } \\
\text { AIR SPECIFICATION }\end{array}$ \\
\hline $\begin{array}{l}\text { Oxygen, Volume } \% \\
\text { Balance Nitrogen }\end{array}$ & 20.9 & N/A & $19.5-23.5$ \\
\hline Carbon Monoxide, ppmv & $<0.2$ & N/A & 10 \\
\hline Carbon Dioxide, ppmv & 678 & N/A & 1000 \\
\hline Water, ppmv / Dewpolnt, of & $21.5 /-67$ & N/A & $63 / .50$ noto 1 \\
\hline $\begin{array}{lll} & \text { TVHC (nelualng namano), ppimv } \\
\end{array}$ & 8.1 & N/A & N/A \\
\hline 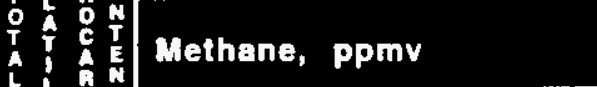 & 3.5 & N/A & N/A \\
\hline TVHC (oxcluding metrano), pprnv & 4.6 & N/A & N/A \\
\hline $\begin{array}{l}\text { Oil (condensed), } \mathrm{mg} / \mathrm{m}^{3} \\
\text { and particulates }\end{array}$ & N/A & N/A & 5 \\
\hline Odor (provided by customer) & None/Slight & N/A & None/Slight \\
\hline
\end{tabular}

This sample COMPLIES with the gas portion only of CGA Grade D air specifications.

(Note 1) This limit applies to the use of self contained breathing apparatus (SCBA). The above limit applies or 10 degrees lower than the coldest temperature expecied in the area. For non-SCBA use the water content may vary with the intended use from eaturated to very dry.

This specification is for a PARTIAL sample, i.e., either a source or filter sample was not submitted for analysis. No certilicate will be issued since full compliance with the eppecification cannot be verified.

Loboratory accredited by the American Association for Laboratory Accreditation (A2LA).

Resits reported relate only to the trems tasted. This repon chal not be reproduced except in fill, without the wituen epproval of this baboratory.

\begin{tabular}{|c|c|c|c|c|c|c|c|}
\hline & Oxycen & Nothane & $\begin{array}{l}\text { Carton } \\
\text { Monoudd }\end{array}$ & $\begin{array}{l}\text { Cobon } \\
\text { Dioxide }\end{array}$ & Water & TVHC & Oiv \\
\hline Acarecy (\%) & $\because 9$ & 100 & 101 & 100 & 87 & 100 & 100 \\
\hline Procision (\%) & 1.1 & 1.4 & 1.2 & 2.5 & 0.3 & 1.1 & 0.6 \\
\hline
\end{tabular}

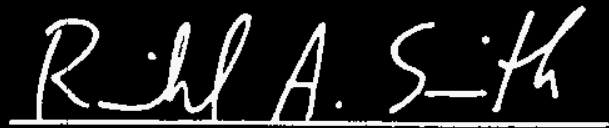

Richard A. Emith, C.I.H. - Laboratory Director 


\section{To: (Receiving Organization)}

Rev. 0

Appendix B-1 of B-15

Poge 1 of $\frac{1}{1}$

Core Sampling

5. Proj./Prog./Dept./Div.:

Core Sampling Aux. Equipment J.L. Smalley

\section{Originator Remarks:}

ETN-94-0023-G

This Acceptance Test Procedure is transmitted for approval.

The procedure was prepared by the Seller and will be

performed at the Sellers location. It will show compliance with specification WHC-S-0251 Rev. 0.

\section{Receiver Renarks:}

\section{From: (Originating Organization) Characterization Equipment}

\section{Cog. Engr.:}

4. Related EDT No.:

N/A

7. Purchase Order No.:

404883

9. Equip./Component No.:

$N / A$

10. Systen/Bldg./Facil ity:

\section{Genera 1}

12. Major Assm. Dwg. No.:

$N / A$

13. Permit/Permit Application No.: $N / A$

14. Required Response Date: 9/9/94

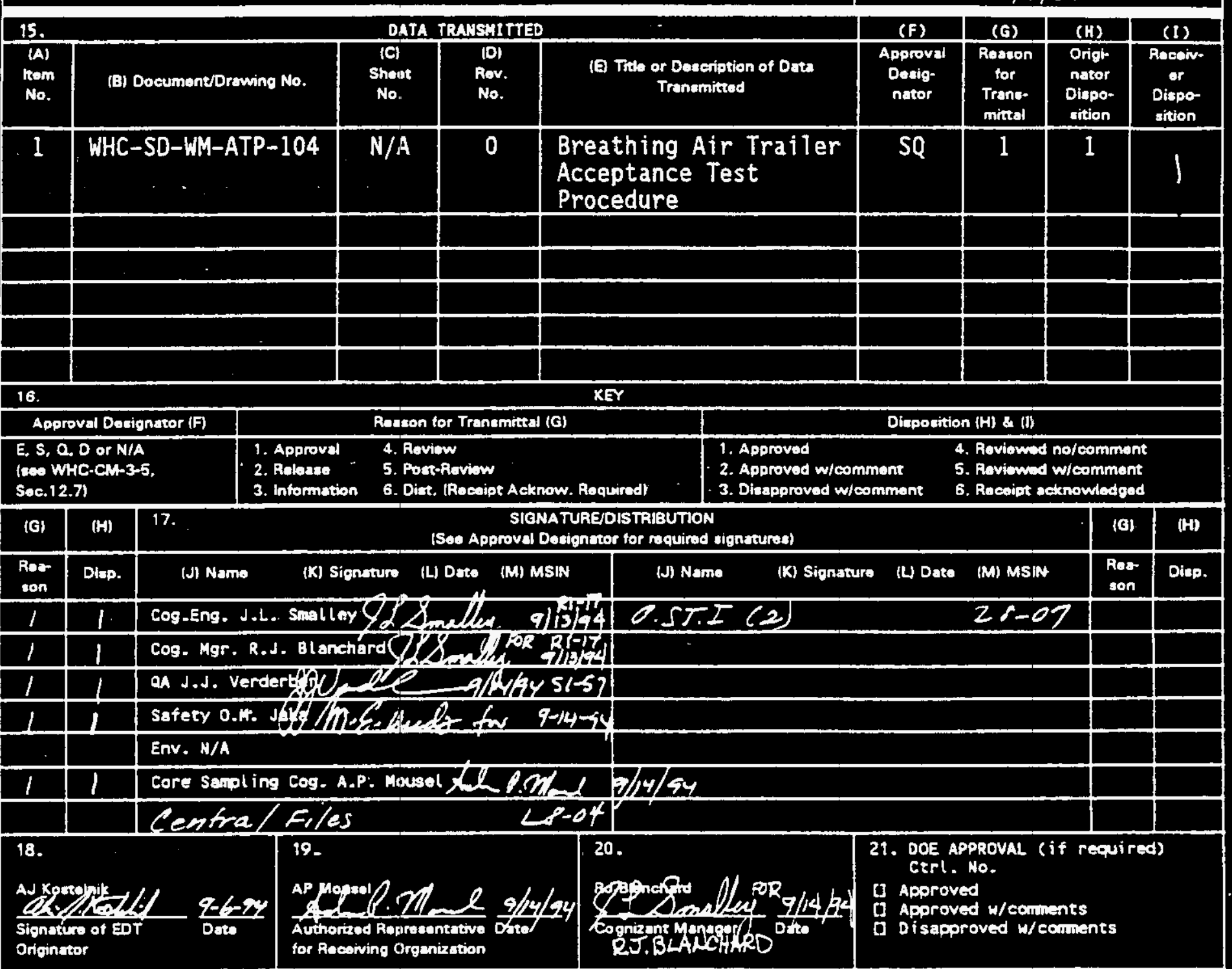




\section{RELEASE AUTHORIZATION}

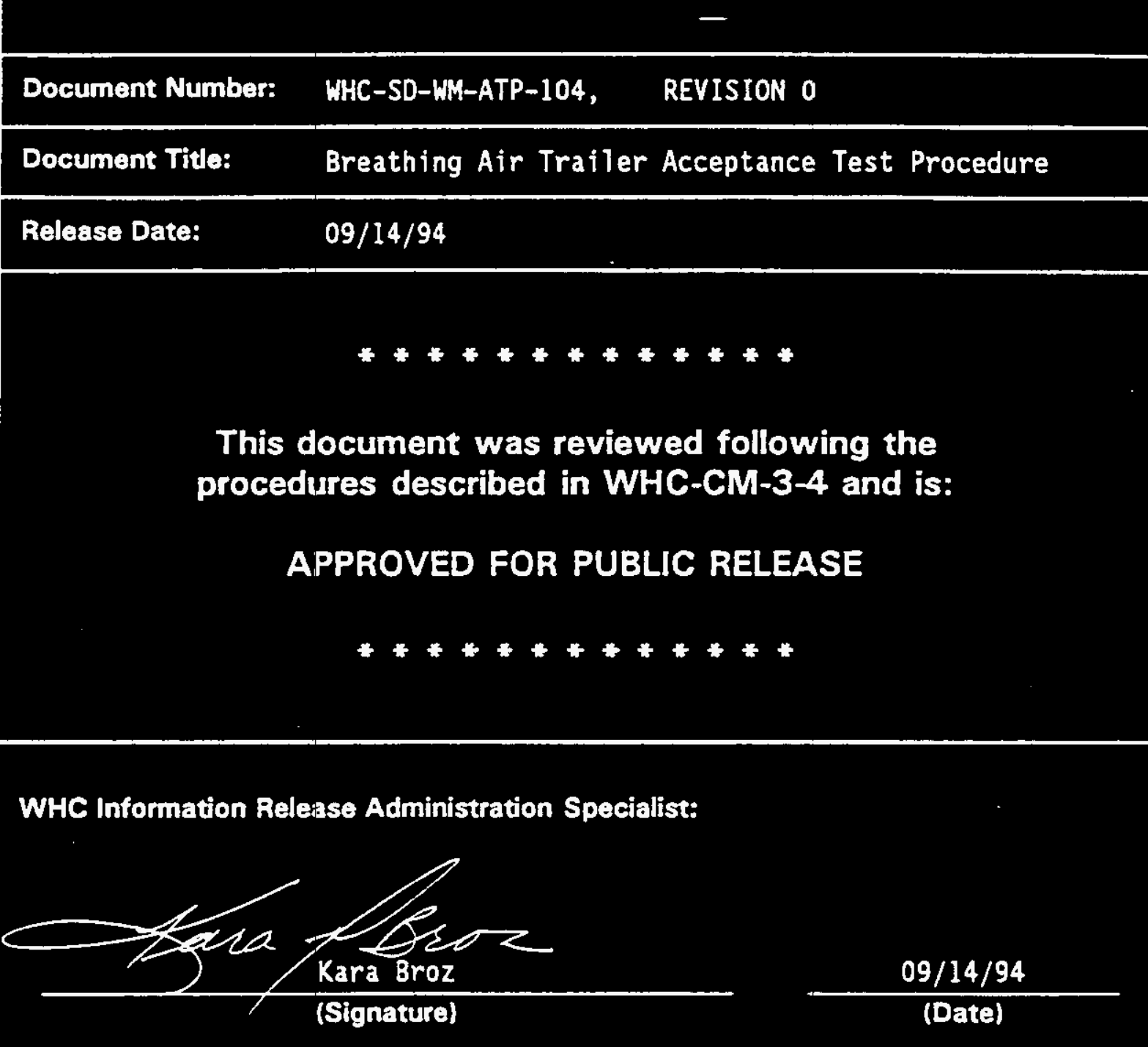




\begin{tabular}{|c|c|}
\hline $\begin{array}{l}\text { 2. Title } \\
\text { Breathing Air Trailer Acceptance Test Procedure }\end{array}$ & $\begin{array}{l}\text { 3. N } \\
\text { WHC-SD-WW-ATP-104 }\end{array}$ \\
\hline $\begin{array}{l}\text { 5. Key Words } \\
\text { ETN-94-0023-G, Core Sampling, Breathing Air, } \\
\text { Speciffication WHC-S-0251, Trailer, American } \\
\text { Bristol, Air Compressor, Purchase Order 404883, } \\
\text { Core Sampl ing Auxiliary Equtpment, Portatte '. } \\
\text { Breathing Air Supply }\end{array}$ & $\begin{array}{l}\text { 6. Author } \\
\text { Name: Alois J Kostelnik }\end{array}$ \\
\hline
\end{tabular}

This Acceptance Test Procedure (ATP) will document compliance with the requirements of WHC-S-0251 Rev.0 and ECNs 613530 and 606113. The equipment being tested is a Breathing Air Supply Trailer purchased as a Design and Fabrication procurement activity. The ATP was written by the Seller and will be performed by the Seller with representatives of the Westinghouse Hanford Company witnessing the test at the Seller's location.

8. Pungose AND USE of DOCUmENT - This document was prepared foe use within the U.S. Departiment of Energy and its contractors. Tt is to be used ondy to perform, direct, or integray work under U.S. Department of Energy contracts. This document is not approved for public release unil reviewed.

PATENT status - This document cof, since it is transmited in advance of patent clearance is made arajiable in confidence solely for use in performanet of work Undox eontracts with the U.S. Department of Etrersy. This document is not we be pubt ished nor its contents otilerwise disseminated or used for purposens other than specified dbove before patent approval for such release druse has beeprecured, upon request, from the Patent Counsel, U.S. Depar thank of Energy field office, Richland, WA.

DISCLAIMER - This report was prepared as an account of work sponsored by an agency of the United States Goverminent. Neither the United States Govermment nor any agency thereof, nor any. of their employees, nor any of their contractors, subcontractors or their enployees, makes any warranty, express or ithol ied, or assumes any legal liability or respons ibility for the accuracy, conpleteness, or any third party's use or the results of such use of any information, apporatus, product, or process disclosed, or represents that its use would not infringe privately ouned rights. Reference herein to any specific connereial product, process, or service by trade name, tradenark, manufacturer, or otherwise, does not necessarily constitute or imply its endorstentent, recammendation, or favoring by the United States Govermant or any ageney thereof or its contractors or subcontractors. The views and opinions of authors expressed herein do not necessarily state or reflect those of the United States Governuent or any agensy thereof.

9. Impaet Level $\mathrm{SQ}$
10.

RELEASE STAMP

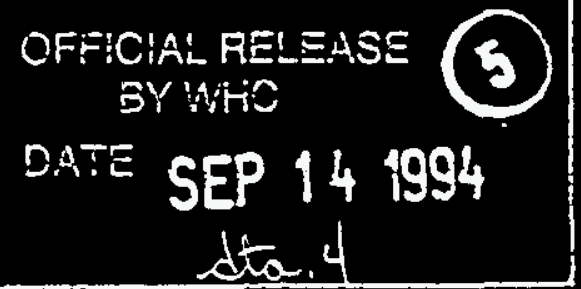




\section{TABLE OF CONTENTS}

TITLE PAGE

1.0 SCOPE

2.0 SEQUENCE

3.0 VISUAL INSPECTION

4.0 OPERATIONAL INSPECTIOHS

5.0 POST OPERATIONAL CHECKOUTS

ACCEPTANCE TEST PROCEDURE NORK SHEETS

TEST EXCEPTIONS
Page 3

Page 4

Page 4

Page 4

Page 4

Page 6

Page 8

Page 11 


\section{ACCEPTANCE TEST PROCEDURE \\ MOBILE BREATHING AIR TRAILER}

YODEL 5014-0001
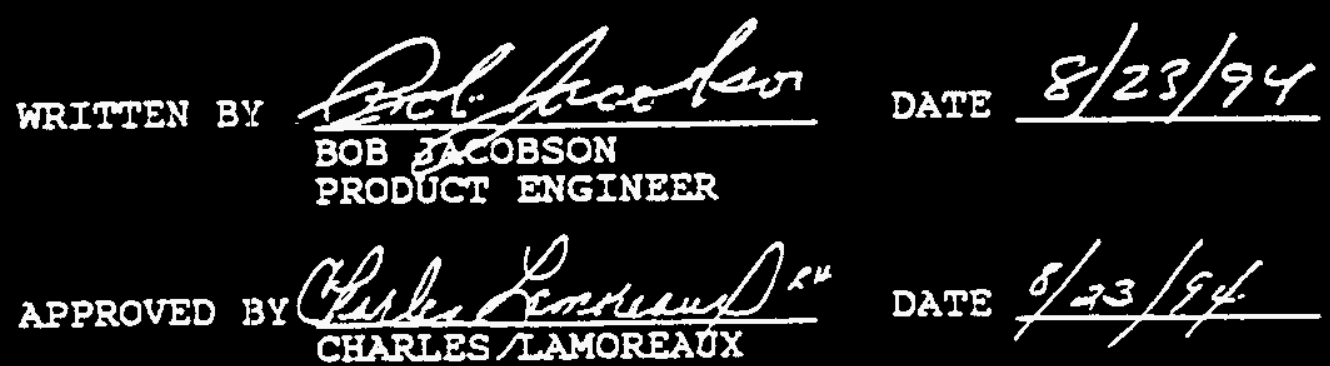
PRESIDENT 


$$
\begin{array}{r}
\text { WHC-SD-WM-ATR-104 } \\
\text { Rev. } 0
\end{array}
$$

Appendix B-6 of B-15

\section{$1.0 \quad$ SCOPE}

This test procedure is to verify that the American Bristol Industries, Ine., Model 5014-0001 low pressure Mobile Breathing Air Trailer, meets or exceeds the requirements of the Westinghouse Hanford specification. (WHC-S-0251)

\subsection{SEQUENCE}

ABI will complete the following tests in the order deemed best by ABI personnel.

\subsection{VISUAL INSPECTION}

Visually inspect the unit to verify that it complies with the requirements of the purchase specification. Record the pertinent data on the data sheets provided.

3.1 Visually inspect the unit for:

3.1.1 Damage.

3.1 .2 Cleanliness; no weld spatter; no foreign materials. 3.1.3 Uniformity of finish: no bubbles, chips, scratches.

3.1.4 All wiring and plumbing secured in place.

3.1.5 All wiring undamaged, connections tight.

3.1.6 All wires tagged.

3.1.7 All major components tagged with manufacturers' nameplates.

3.1 .8 ABI nameplate stamped installed.

3.1.9 VIN number stamped on unit.

$3.1 .10^{\circ}$ All ground wires properly connected.

3.1.11 Verify that lunette eye ID is 2.75 inches minimum.

4.0 OPERATIONAL INSPECTIONS

4.1 Break-in Inspections

4.1.1 Verify incoming power at the magnetic starter.

4.1.2 Verify proper compressor rotation before starting break-in procedures. 
4.1.3 Operate each unit in accordance with the break-in schedule table on the data sheets. Record the start up current and the running current.

4.1.4 During break-in, carefuliy observe the unit for any evidence of excessive vibration, excessive heat, strange noises, odors, etc., loose components, interferences between components and leakages. Correct as required.

\subsection{Leak Test}

4.2.1 Upon completion of the break-in test, shut the system down with the rated pressure trapped in the system. Bubble test all fittings, joints, valve stems, burst discs, etc. for any evidence of leakage. Correct as required. (Working pressure 80-125 psig)

4.2.2 Attach hose and manifold to system and pressurize to working pressure. Bubble test all joints for any evidence of leakage. Correct as required.

\subsection{Relief Valve Test}

4.3.1 With the unit running, activate all relief valves to verify each valve will flow.

4.3.2 Verify each relief valve reseats and does not leak.

\subsection{Condensate Drain Test}

4.4.1 With the unit running, verify that there are no leaks in the automatic condensate drain system by immersing the drain tube in water and observe any leakage. correct as required.

4.4.2 Record the time between dump cycles and the duration of the dump.

4.4.3 Allow the system to shut off automatically. Verify that the dump valves open and that the compressor continues to run in its cool down mode. Record the time of the cool down run.

4.4.4 close the interstage and filter manual drain valves. Bring the system up to pressure and shut off. Observe for leakage by immersing the drain tube in water.

\subsection{Compressor Operational Test}

4.5.1 Measure compressor output per standard practice sheet or by use of a pressure gauge and a flow meter. Record the data. 
4.5.2 Record the rotational speed of the compressor.

4.5.3 Record the temperature of the air receiver at its discharge while flowing air at rated pressure and flow.

4.5 .4

4.5 .5 Take an air sample in accordance with the sampling company's procedures and ship the sample for analysis.

Shut down the system and allow it to cool to room temperature. After it has cooled down, run it again for 5 minutes with the intercooler drains open to remove any additional condensation.

4.6 Monitor / Controller Operational rest

4.6.1 Verify that the Automatic start/stop function operates.

4.6.2 Verify that the yanual start/stop function operates.

4.6.3 Verify that the high temperature stop operates properly.

4.6.4 Verify that the low oil stop operates properly.

4.6.5 Verify that the high $c 0$ portion of the monitor operates in accordance with its manual. (Set at 10ppm and 25ppm)

4.6.6 Verify that the high dew point portion of the monitor operates in accordance with its manual.

4.6.7 Verify the low pressure sensor actuates the reserve air supply. (and there is adequate supply for 5 minutes.)

4.6.8 Verify that the audio/visual alarms function whenever any of the above safety features are actuated.

4.7 Filters, Dryer, and Chiller Operation

4.7.1 Verify that the filters have the correct elements installed.

4.7.2 Verify that the swing dryer has the correct chemicals installed and that it functions in accordance with its operating manual.

4.7.3 Verify that the chiller functions in accordance with its operating manual.

5.0 POST OPERATIONAI, CEECKOUTS

5.1 Verify all tires are at recommended inflation pressure

5.2 Set the parking brake. Verify that the parking brakes hold by pushing/puliing the unit. The wheels should skid instead of rolling. Adjust as reguired. 
5.3 Verify the surge brakes actuate by towing the unit and applying the brakes. The unit should not push the tow vehicle nor fish tail. Adjust as required.

5.4

5.5

5.6

5.7

5.8

5.9

5.10

5.11
Verify that the compressor oil level is full.

Verify that the surge brake system is full of brake fluid.

Record final hour meter reading.

Verify that all components are securely mounted.

Verify that the cable reel fully extends and retracts. Verify that the main landing jack and leveling jacks extend and retract and that the leveling jacks pivot and lock out of the way.

Verify that all Dor lights are functional.

Verify that the brake lights, back up lights and turn signals are functional. 
Order: $\frac{12234}{5014-0001}$ Comiguration: OPERATOR:

NO. TREST DESCAIPTION

CUSTOMER:

\section{Sorial * 98940602-9}

$\angle P$ MeACT $24 N / 37$ INSPECTOR: Galler?

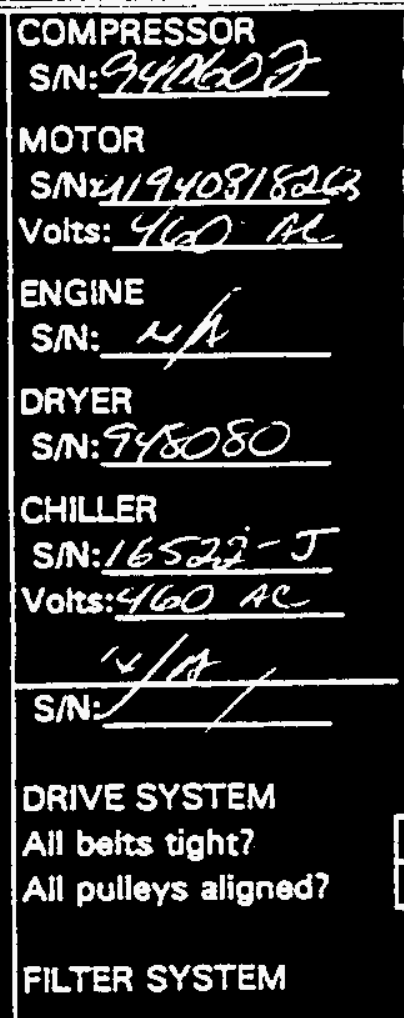

Make:

CFM:

Make:

HP

Phase

Make:

HP

Make: Srane

CFM:

100

Make: GuATCdes

CFM:

Phase

Make:

CFM:

Acoreos

20

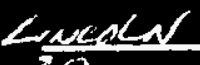
30

3

3

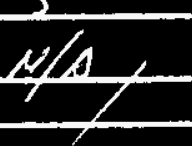

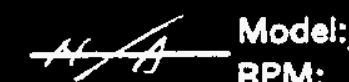

RPM:

Model: $A L-100$

Psi: $\angle \widehat{S O}$

Model: 2 and $13 \%$

PSi: 200

Model:Pare wisplens

RPM: 7760

Hz: $\quad 6 \theta$

$1 / \alpha+y$

TCAlYs Model: 542100

PSI: $\sqrt{50}$

Hz:

60

Mode:

PSt:

Yes

Chamber No

Model No $1055-R G D$

CFM:

100 PSI: 50

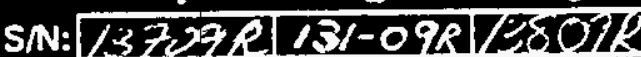

Logged? Yes [D Yes [Z] Yes LU Yes

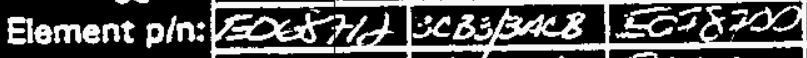

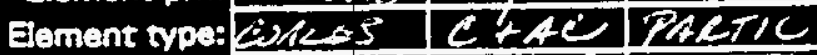

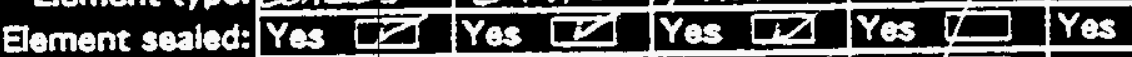

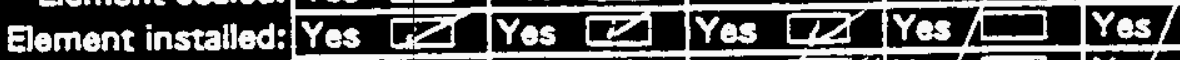

Chamber backed off: Yes LIM

Burst disk PSI:

Drain Valve Oos OK

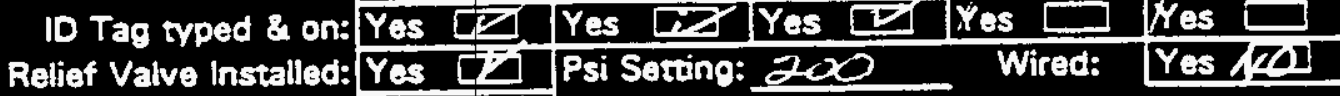

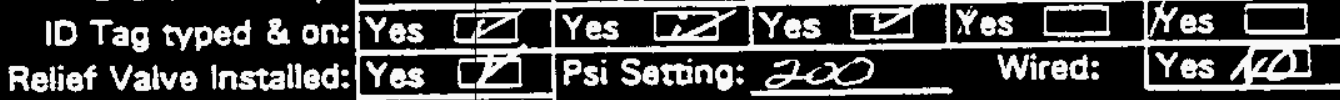

I/

Yula

N/fs

Teg

4

5

4 Mity

\section{ore}

$-2$ INTTLALS

Check Valve Installed: Yes [Z].

WLET FILTER

Installed: Yes th Element installed

Yes

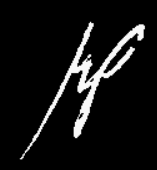

STORAGE SYSTEM

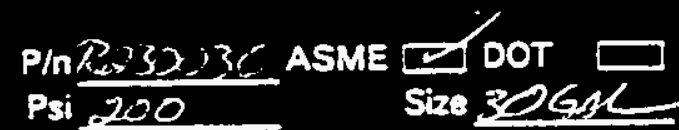

ov

$\longrightarrow$

$\longrightarrow$
2 


\section{ACCEPTANCE TEST PROCEDUAE WORK SHEE}

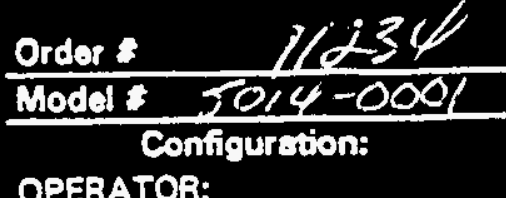

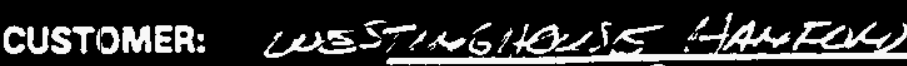

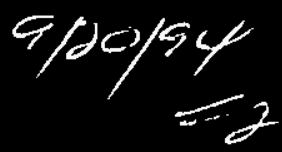

$\cdots \angle P$ HACI $24 \times 137$

OPERATOR: INSPECTOR: Gake $<\infty<$

\section{NO. TEST DESCAIPTION}

\section{I}

3.0. VISUAL BXAMINATION

3.1.1 No damage:

3.1.2 Clean, no weld spatrer,foreign material:

3.1.3 Finish : Uniform, no bubbles, ehips nor scratches

3.1.4 Wiring 8 plumbing secured:

3.1.5 No damage to wires, All connoctions tight 8 in place:

3.1.6 All wires tagged

3.1.7 All major components taosed with mig' $r$ 's nameplates:

3.1.8 ABI nameplate stamped 8 installed:

3.1.9 ViN number stamped on unit

No: $149 \operatorname{cH} 222024079113$

3.1.10 All wires grounded:

3.1.11 Lunotte eye it $>2.75$ inches 2.87

4.0. OPERATIONAL INSPECTIONS AND TESTS

4.1 Break in Inspections

4.1.1 Voltage: "4601230IVAC

4.1.2 Proper Rotation:

(CCW)

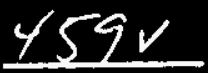

Current:

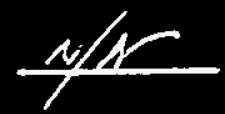

4.1.3 Operate each unit according to the following table and record start up and running current

\begin{tabular}{|c|c|c|c|c|}
\hline Motor & Engine & Speed & Load & Current \\
\hline $30 \mathrm{Min}$ & & Rated & Low & 1804 \\
\hline $3-4$ Hrs. & & Rated & Rated & N/A \\
\hline & 15-30 Min & Fast ldle & Min & 2 \\
\hline & $1 \mathrm{Hr}$ & Rated & Light-Med & \\
\hline & $2-3$ Hrs & Rated & Rated & \\
\hline \multirow{4}{*}{\multicolumn{2}{|c|}{$\begin{array}{l}\text { Excessive heat } \\
\text { Strange noises } \\
\text { Strange odors } \\
\text { Other } \\
\text { Vibration }\end{array}$}} & \multicolumn{3}{|l|}{10} \\
\hline & & \multicolumn{3}{|l|}{ No } \\
\hline & & \multicolumn{3}{|l|}{ so } \\
\hline & & \multicolumn{3}{|l|}{$\pi(5)$} \\
\hline
\end{tabular}

\subsection{Leak Test}

4.2.1 No leaks in system

4.2.2 No leaks in hoses Buablas Lathes on/y

4.3 Relief Valve Test

4.3.1 Activate all relief valves

4.3.2 All relia valves reseat

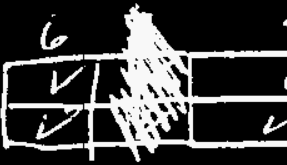

4.4 Condensate Drain Test

4.4.1 Does not leak during operation

4.4.2 Time between dump cycles

$34 \pi$

Duration of dump

4.4.3 Veriy dumps open during Cool Down \& Purge

4.4.4 Does Dox leak after shut off $y \in S$ Tine

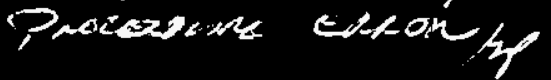

$\frac{k \in 3}{y \in S}$ Time

\section{NTIALS}
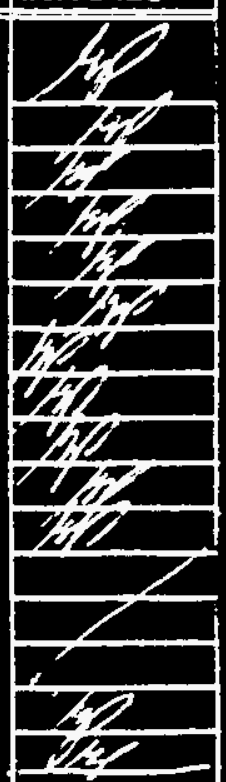
ACCEPTANCE TEST PROCEDURE WORK SHE

Order * $1 / 234$

Model : SE $14-0001$

Configuration:

OPERATOR:
CUSTOMER:

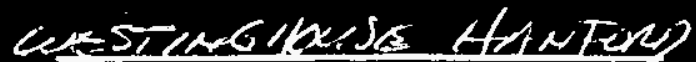

Serial $9290602-9$

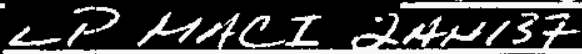

INSPECTOR: Getere tesid

NO. TEST DESCAIPTION

4.5 Compressor Operational Test ESE10OPSI 92080 FLAwNETEn

4.5.1 Measure Output

Ala minutes to fill a

Mi/R psi

4.5.2 Compressor

4.5.3 Temperature

4.5.4 Take Air Sámple

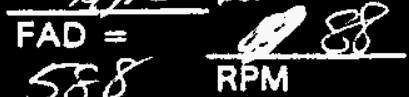

SCFM

588 RPM

372

Results

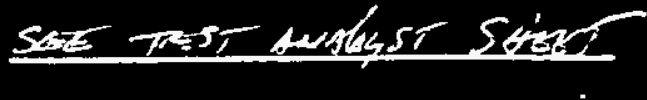

4.5.5 After cool down to room temp run for 5 minutes with drains open

4.6 Monitor / Controller Operational Test

4.6.1 Auto start / stop

4.6.2 Manual start / stop

4.6.3 High temperature stop $\propto 350^{\circ} F$

4.6.4 Low oil stop $\odot 20$ PS: FA/ING

4.6.5. Hi CO operation

10ppin_ $y=5$

4.6.6 Hi dew point operation

4.6.7 Low air pressure sensor operation and 5 minutes reserve air available.

4.6.8 Audio / Visual alarm functions with all of the above

4.7 Filters, Dryer and Chiller Operation

4.7.1 Correct filter elements installed

4.7.2 Chemical installed in swing dryer ALumut F20 3/160 Operates properly

4.7.3 Chiller operates properly

5.0. POST OPERATIONAL CHECKOUTS

5.1 Tire pressure

5.2 Parking brake functions property

5.3 Surge brake functions property

5.4 Compressor oil level FULL.

5.5 Surge brake system oil level

5.6 Hour Meter Reading

25ppm EANAD, VERCH, NO JOUKCE

Toty

.

INTIALS

5.7 Alt components securely mounted. No loose bolts, nuts, pins, etc..

5.8 Cable reel pays out and picks up cable

5.9 Main landing jack extends $\&$ retracts

Leveling jacks extend, retract $\&$ pivot $\&$ lock out of the way

5.10. DOT lights are functional

5.11 Brake lights, tum signals, \& backup lights are functional

I hereby certify that the above data is trye and orrpect

oc inspector

Date

page 3 of 3

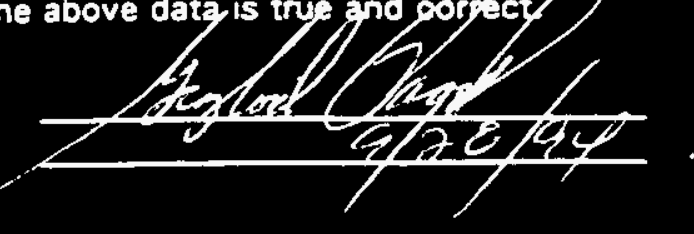


anto

titit

$4+3$

TEST EXCEPTIOMS

step

Description of exception and resolution.

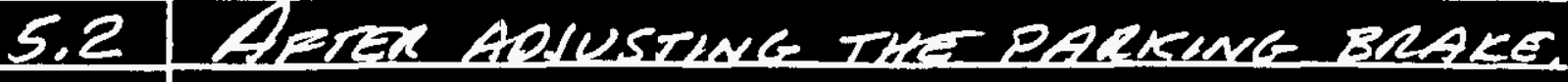

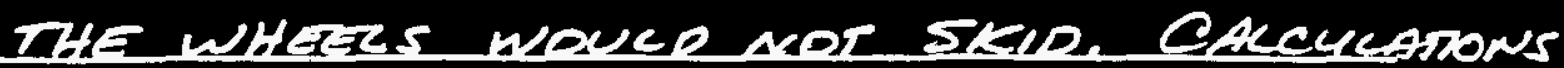

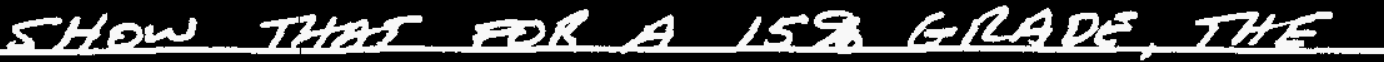

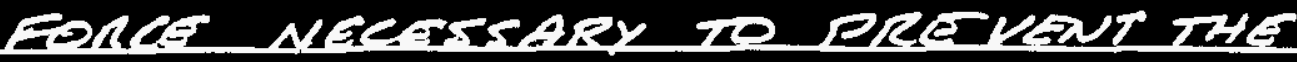

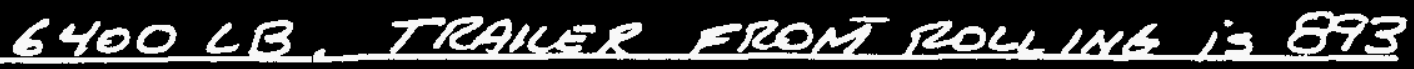

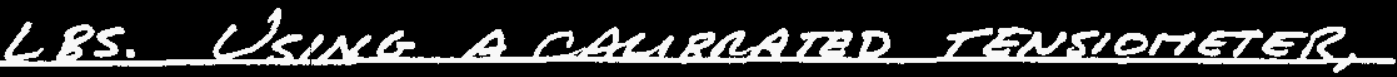

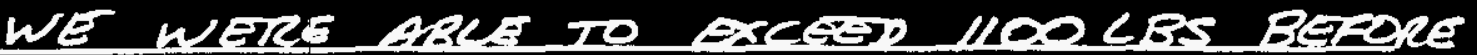

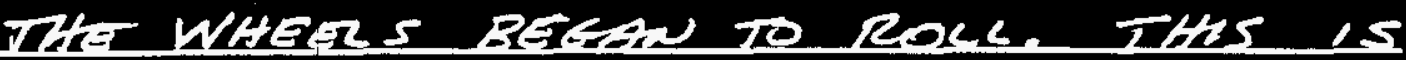

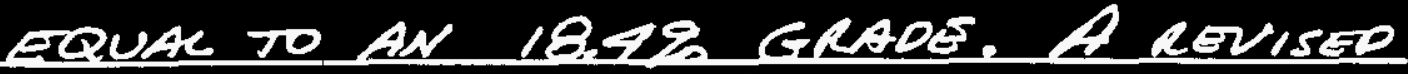

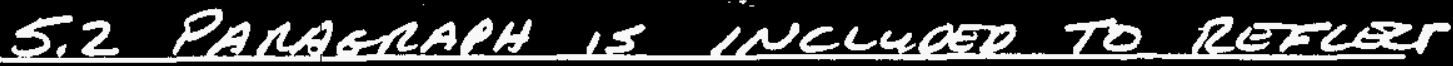

THE CHARG $N$ THE ATP

ATP REVISION PARAGRPH 5.2:

SET THE PARKING BRAKE. KGLEY THA IIE PRCKLNG BRAKE HOLOS BY PUSHING OR pURLRUR THE UNIT. THE BRAKE SHOULD

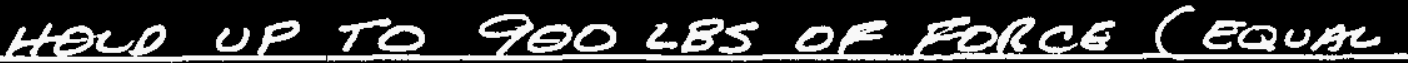

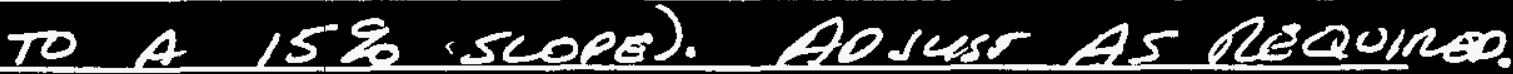

TEST COMPLETED BY:

\begin{tabular}{|c|c|}
\hline PRINT NAME & SIGNATURE \\
\hline 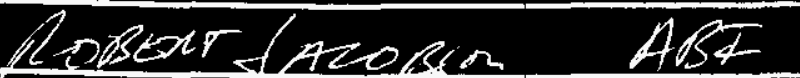 & Solut thatran \\
\hline & \\
\hline & \\
\hline & \\
\hline
\end{tabular}


$\therefore \quad$ Dus: $10-31-94:$

$A^{\prime \prime} 4 C-S J-W M-A T R-104$

Appendix B-14 of B-15

DATE $10-31-94$

s.0. 112.234

REQUEST EOR FILTER TAGS

$\therefore$

CARTRIDGE:

1) $\frac{206712}{290}$

2) $3 C B-3 / 3 A C B$

3) $E 0 \mp 8700$

4) $=078700$

MODEL:

1OSS-RGD w.P. 250

PSI

SERtal: $\quad 1137-0.98$

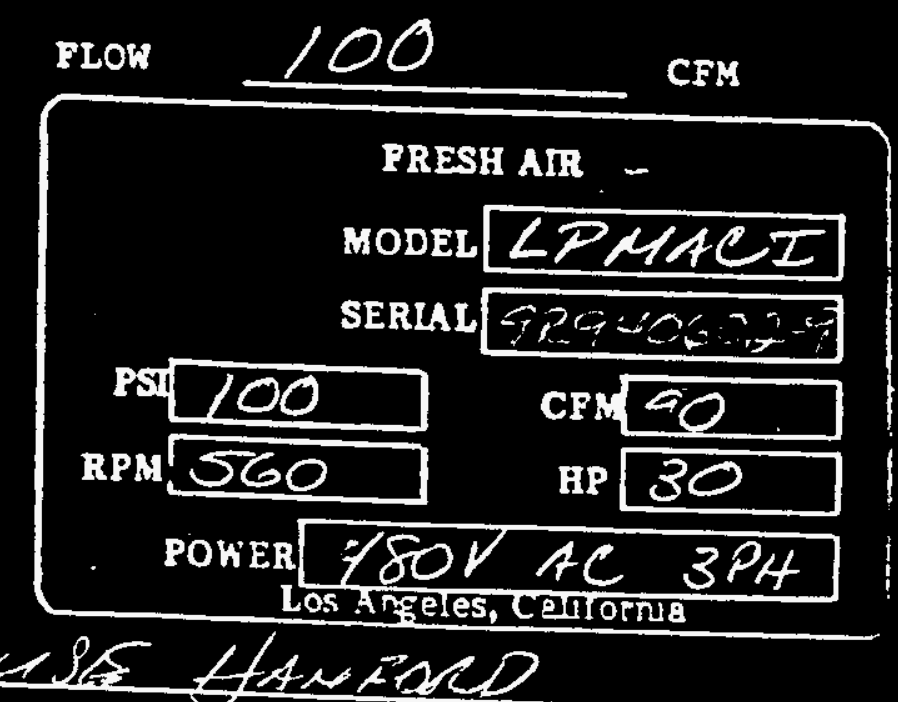

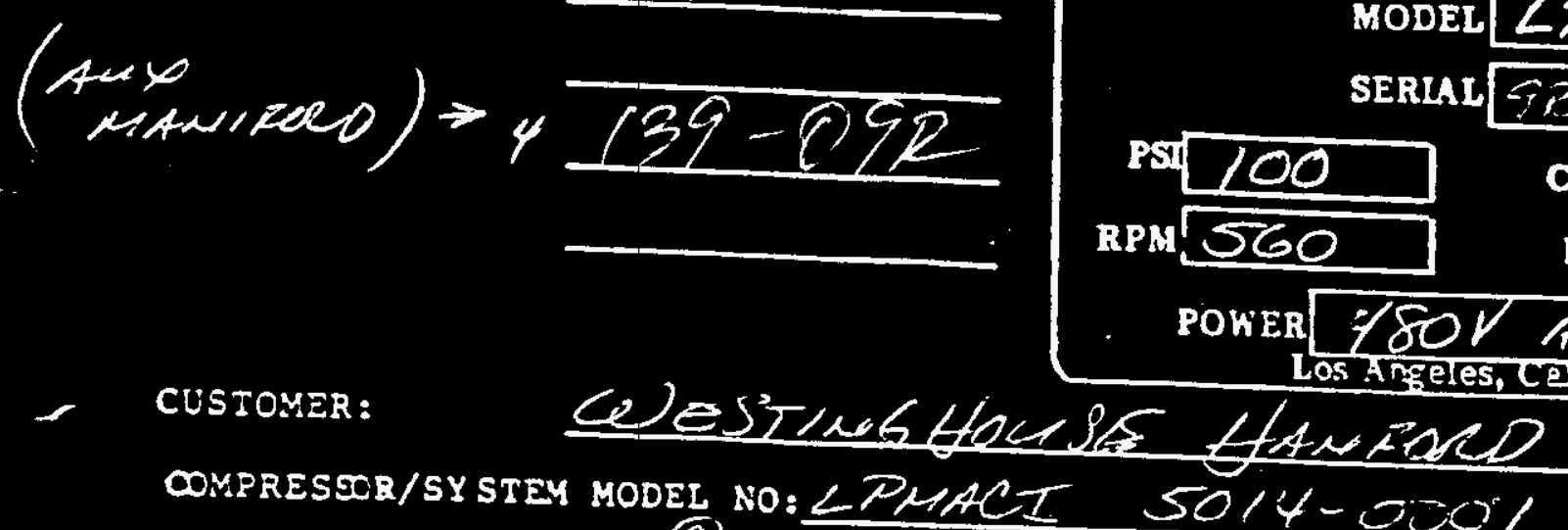
COMPRESSOR/SY STEY MODEL NO: $\angle$ PMACT $5014-000 \%$ COMPRESSOR UNIT S/N : (3) is . .

SYSTEM $S / N$ :

manat: $\quad$ El

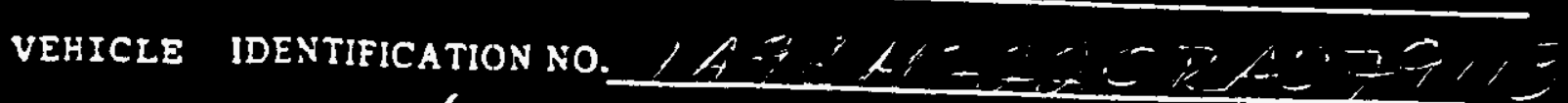

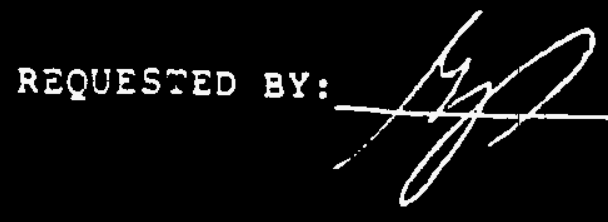


P.O. Eax 160850 - Austin, TX78716 - 800-ANR-1024 - 512-320-4076 - FAX 512-328-4122

Customer" 123

American Bristol Ind.

Mr. Chuck Lamoreaux

1600 W 240 th St.

Harbor City, CA 90710
Report No.: 94-3847

Date Analyzed: October 27, 1994

Sampled By: K. Lamoreaux

Date Sampled: October 26, 1994

Air Source ID: L. P. Trailer \# 2 S/N 1A9CM222ORA079113

\section{Sampled for Westinghouse Hanford}

COMPRESSED AIR ANALYTICAL RESULTS

\begin{tabular}{|c|c|c|c|}
\hline $\begin{array}{c}\text { LIMITING } \\
\text { CHARACTERISTIC }\end{array}$ & $\begin{array}{l}\text { SOURCE AIR } \\
\text { RESULTS }\end{array}$ & $\begin{array}{l}\text { AMBIENT AIR } \\
\text { RESULTS }\end{array}$ & $\begin{array}{l}\text { CGA Grade D } \\
\text { AIR SPECIFICATION }\end{array}$ \\
\hline $\begin{array}{l}\text { Oxygen, Volume } \% \\
\text { Balance Nitrogen }\end{array}$ & 21.0 & N/A & $19.5-23.5$ \\
\hline Carbon Monoxide, ppmy & $<0.2$ & N/A & 10 \\
\hline Carbon Dioxide, ppmy & 101 & N/A & 1000 \\
\hline Woter, ppmv / Dewpolnt, of & $5.6 /-85$ & N/A & $63 /-50$ note 1 \\
\hline 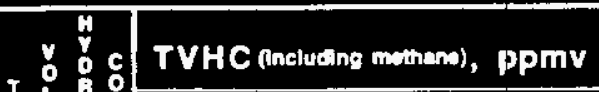 & 6.9 & N/A & $N / A$ \\
\hline 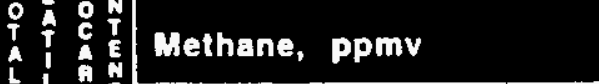 & 3.1 & $N / A$ & N/A \\
\hline 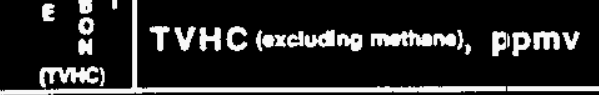 & 3.8 & N/A & $N / A$ \\
\hline $\begin{array}{l}\text { Oll (condensed), } \mathrm{mg} / \mathrm{m}^{3} \\
\text { and particulates }\end{array}$ & N/A & $N / A$ & 5 \\
\hline Odor (provided by customer) & None/Slight & N/A & None/Slight \\
\hline
\end{tabular}

This sample COMPLIES with the gas portion only of CGA Grade D air specifications.$$
\text { Laboratory accredited by the American Association for Laboratory Accredltation (A2LA). }
$$

Resuts reponted relate only to tha flams tasted. This repon stal not be reproduced except in tul, without the withen epproval of this laboratory.

\begin{tabular}{|c|c|c|c|c|c|c|}
\hline Oxypen & MEthera & Centon & $\begin{array}{l}\text { Copton } \\
\text { Dioxide }\end{array}$ & Water & TVHC & $\begin{array}{l}\text { Oiv } \\
\text { Pat }\end{array}$ \\
\hline 89 & 100 & 101 & 100 & 97 & 100 & 100 \\
\hline 1.1 & 1.4 & 1.2 & 2.5 & 0.3 & 1.1 & 0.6 \\
\hline
\end{tabular}

(Note 1) This limit applies to the use of self contained breathing apparatus (SCBA). The above limit applies or 10 degrees lower than the coldest temperature expected in the area. For non-SCBA use the water content may vary with the intended use from saturated to very dry.

This specification is for a PARTIAL sample, l.e., ether a source or fitter sample was not submitted for analysis. No certificate will be issued since full compliance with the epecification cannot be verified.

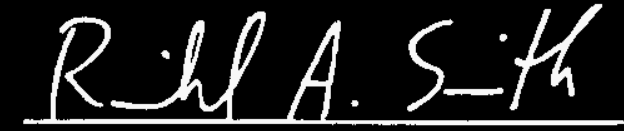

Pichard A. Smith, C.I.H. - Laboratory Director 
From: Electrical Power Systems Engineering

Phone: 376-8109 L4-90

Date: October 17, 1994

SUbject: CORE SAMPLING EQUIPMENT BREATHING AIR COMPRESSORS

To: Al Kostelnik Rl-17

CC: CMM File/LB

\section{Unit Descriptions}

Two breathing air compressor units have been assembled by American Bristo? Company, 1600 West 240 th Street, Harbor City, California from components supplied by a variety of vendors.

The units consist of an industrial control panel, a $30 \mathrm{hp}$ electric motor connected by belt drive to the compressor, a chiller with hermetic sealed compressor, and a swing dryer.

FLA for the motor is 37 amps, 4.5 amps for the chiller and 1 amp for the dryer.

The control panel was manufactured by Klockner-Mueller under their UL label for industrial control equipment. The control panel includes the main disconnect switch and main overcurrent protection devices, three 60 amp fuses.

The power is supplied through a 4 conductor \#6 flexible cord installed on a Hannay brand cord reel. The four brush slip ring is rated 50 amps. The cord reel model is CR 1616-17-18. There is no evidence of a UL label on the cord reel, it is suspected that the manufacturer, a well known long established manufacturer of electrical cord reels has a UL listing available for this device.

The motor is a Lincoln Totally Enclosed Fan Cooled (TEFC) high efficiency $1760 \mathrm{RPM}$ motor of $30 \mathrm{hp}$ at 480 volts three phase. This motor is a split winding soft start motor having a nameplate FLA rating of 37 amps. The windings are split evenly. Therefore a winding FLA of 18.5 amps is used to calculate conductors and overload protection. The conductors are $3 \# 10$ THWN/THHN per winding. Both sets of conductors are in the same conduit. Derating for conduit fill still allows adequate conductor ampacity. The overload protection is by solid state motor overloads set at 21 amps.

Items requiring further attention

1. There were several small discrepancies noted during the initial visual inspection. These were communicated directly to the Production Engineer. Correction of the discrepancies was accomplished during the site visit. 
Al Kostelnik

Page 2

October 17, 1994

2. The liquidtight flexible metal conduit between the EMT raceway and the motor terminal housing is not secured within 12 inches of the motor enclosure as required by NEC Article 351-8.

3. The cord reel slip rings are rated for 50 amps. The flexible cord is rated for 55 anps. Therefore the circuit supplying this unit shall be no larger than 50 amps.

4. There are several drawing errors noted. The Rev $C$ drawing shows contacts and overloads after the 60 amp supply fuses. This is not the case. The 60 amp fuses are on the load side of a disconnect, there are no contacts or overloads associated with the fuses. The fuses shown on the schematic do not have the amp rating or type of fuse specified. For instance the input fuses are 60 amp class $R$ fuses, in the proper fuse holders. The schematic does not document the type of fuse required.

\section{Recommendations}

1. No action is necessary for this item.

2. Receipt inspection of the liquidtight flexible metal conduit for proper support is required.

3. The generator provided to supply the breathing air compressor has been verified as having the proper overload and fault protection to supply this unit. No futher action is necessary.

4. Receipt inspection of the schematic drawing for as built errors will be required.

\section{Conclusion}

There are no NEC violations or electrical safety concerns that should prevent this unit from safely performing it's intended function.

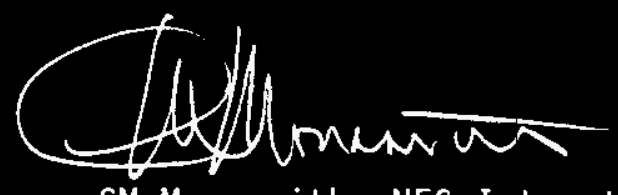

CM Monasmith, NEC Interptative Authority

Electrical Power Systems Engineering

rmg 
1600 W. 240 th street

Harbox City, CA 90710

(310) $534-5981$

$\operatorname{Fax} 310-539-0430$

FACSIMILE TRANSMISSION

\begin{tabular}{|l|l|l|}
\hline COMPANY: & FESTINGHOUSE HANFORD COMPANY & \\
\hline ATTN: & AL KOSTELNIK & OUR FAX NO: 310-539-0430 \\
\hline FROM: & BOB JACOBSON & NO. OF PAGES INCL. COVER: \\
\hline DATE: & 6 OCTOBER 1994 & \\
\hline SUBJECT: & EMGRGENCY AIR SUPPLY TEST & \\
\hline
\end{tabular}

Attached plcasc find a copy of our tast data for tho 5 minuta amargonoy air suplíy LeSL.

We are charging the two units here to the new reglilators and $=0$, tubs tug

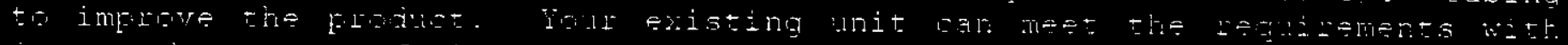
iust a chango olit az tho rogulators. 
WESTINGHOUSE

EMERGENCY AIR SUPPLY TEST

WHC-SD-WM-ATR-104

Rev. 0

Appendix $\mathrm{C}-4$ of $\mathrm{C}-8$

Replaced existing regulator with High flow model Aqua Environments p/n 873 -

150

Used existing $1 / 4^{\prime \prime}$ tubing (.049 wall) and $3 / 16^{\prime \prime}$ ID

hoses

$\begin{array}{rrrrrrrr} & \text { TANK } & \text { OUTLET MEASURED } & \text { AIR } & \text { AMB CORRECTION } & \text { ACTUAL } \\ \text { TIME } & \text { PSI } & \text { PSI } & \text { FLOW } & \text { TEMP } & \text { TEMP } & \text { FACTOR } & \text { FLOW } \\ 0.0 & 4400 & 90 & 72 & 61 & 69 & 0.9915 & 72.62 \\ 0.5 & 3300 & 90 & 72 & 59 & & 0.9896 & 72.76 \\ 1.0 & & & & & & & \\ 1.5 & 2600 & 85 & 72 & 52 & & 0.9829 & 73.25 \\ 2.0 & 2100 & 85 & 72 & 47 & & 0.9781 & 73.62 \\ 2.5 & 1200 & 85 & 72 & 43 & & 0.9742 & 73.91 \\ 3.0 & & & & & & & \\ 3.5 & 900 & 80 & 72 & 34 & & 0.9654 & 74.58 \\ 4.0 & 550 & 80 & 72 & 31 & & 0.9625 & 74.80 \\ 4.5 & 200 & 75 & 70 & 29 & & 0.9605 & 72.88 \\ 5.0 & 0 & 50 & 70 & 24 & & 0.9556 & 73.25 \\ \text { END } & 200 & 110 & 0 & 21 & & & \end{array}$

THIS SHOWS THAT THE NEW REGULATOR AND EXISTING PLUMBING WILL DO 72 SCFM FOR 5 MINUTES

We replaced the $1 / 4$ tubing with $3 / 8^{\prime \prime}$

$\begin{array}{rrrrrrrr} & \text { TANK } & \text { OUTLET MEASURED } & \text { AIR } & \text { AMB CORRECTION } & \text { ACTUAL } \\ \text { TIME } & \text { PSI } & \text { PSI } & \text { FLOW } & \text { TEMP } & \text { TEMP } & \text { FACTOR } & \text { FLOW } \\ 0.0 & 4800 & 92 & 72 & 67 & 69 & 0.9972 & 72.20 \\ 0.5 & 3800 & 92 & 72 & 55 & & 0.9857 & 73.04 \\ 1.0 & 3300 & 90 & 72 & 53 & & 0.9838 & 73.18 \\ 1.5 & 2800 & 90 & 72 & 50 & & 0.9810 & 73.40 \\ 2.0 & 2400 & 90 & 72 & 45 & & 0.9761 & 73.76 \\ 2.5 & 2000 & 90 & 72 & 42 & & 0.9732 & 73.98 \\ 3.0 & 1600 & 88 & 72 & 37 & & 0.9684 & 74.35 \\ 3.5 & 1300 & 90 & 69 & 34 & & 0.9654 & 71.47 \\ 4.0 & 950 & 86 & 69 & 31 & & 0.9625 & 71.69 \\ 4.5 & 550 & 85 & 72 & 27 & & 0.9586 & 75.11 \\ 5.0 & 0 & 80 & 70 & 24 & & 0.9556 & 73.25 \\ \text { END } & 350 & 115 & 0 & 21 & & & \end{array}$

correction factor $=$ square root of $[(460+$ air temp $) /$ 530] 
WHC-SD-WM-ATR-104

Rev. 0

actual flow $=$ measured flow $/$ correction

Appendix $\mathrm{C}-5$ of $\mathrm{C}-8$ factor

(ref: Hedland Div of Racine Federated, manufacturer oi flow meter) 


\author{
is00 W. 24 tith Btret \\ larbor citiy, : \\ (3]0) $53 \div \cdot 0901$ \\ Fix $370-39500430$
}

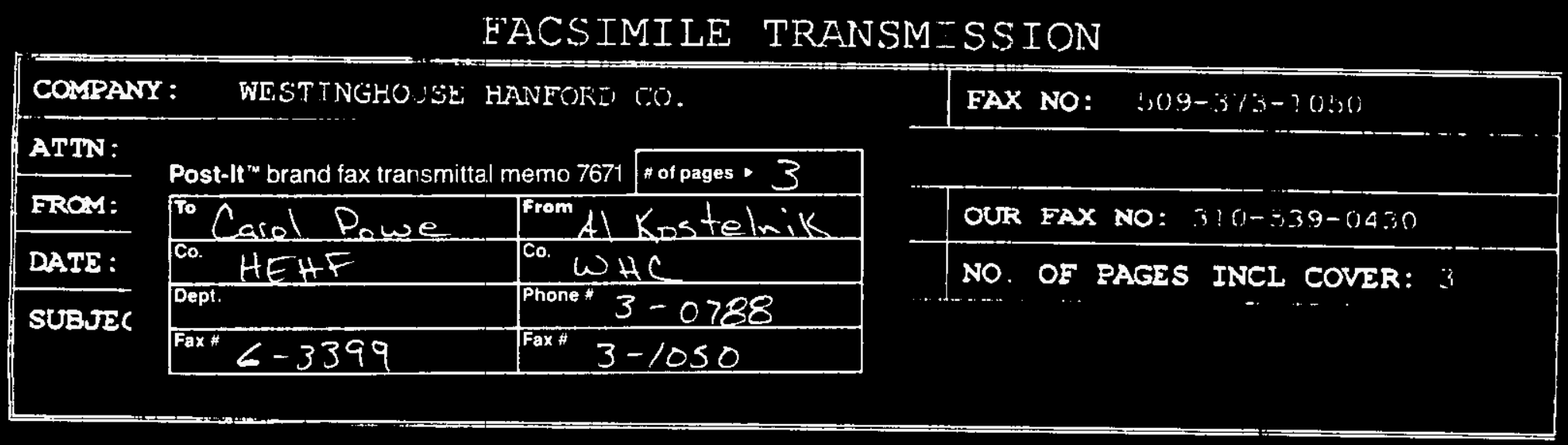

AIK QUALIIY 'LESIIING

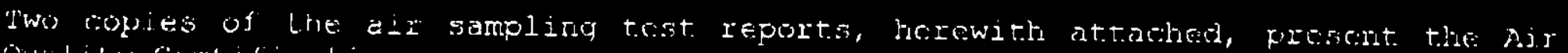
Oualily Corl.ifications.

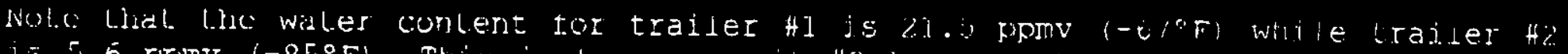

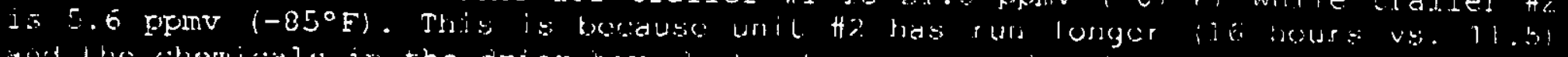

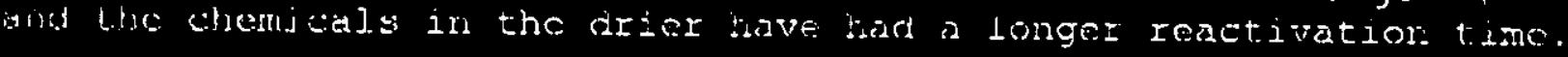

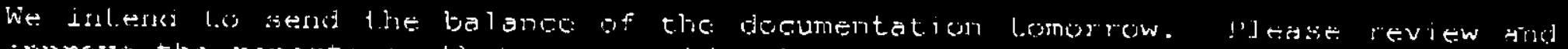
approve the reports so that. we mal ship the unils at the carlicat possiblo moment, hopefully next week.

Carol, Powe HEHF

Please check these test-results and Let me know if you see anything that could be aproblem.

$$
\begin{aligned}
& \text { Thanx' } \\
& \text { 4/ Kostelnik } \\
& 3-0>88
\end{aligned}
$$

Response, 10/31/94 FrowEd Smith, HEFF $\mathrm{CO}_{2}$ levels should be the same but otherwise no problem. 


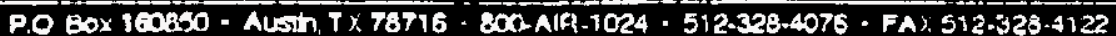

Customerk 123

Amerlcan Briotol Ind.

Mr. Chuck Lamoreaux

$1600 \mathrm{~W} 240$ th St

Harbor City. CA 90710
Report No.: 94-3847

Dale Allalyzed: October 27, 1994

sampled By: K. Lamoreaux

Date Samplea: October 26, 1994

Alr source ID: L. P. Trailer \#2 SN 1 A9CM222ORA079113

\section{Sampled for Westinghouse Hanford}

COMPRESSED AIR ANALYTICAL RESULTS

\begin{tabular}{|c|c|c|c|c|}
\hline \multicolumn{2}{|c|}{$\begin{array}{c}\text { LIMITING } \\
\text { CHARACTERISTIC }\end{array}$} & $\begin{array}{l}\text { SOUACE AR } \\
\text { REBULTS }\end{array}$ & $\begin{array}{l}\text { AMBIENT AIR } \\
\text { REBULTB }\end{array}$ & $\begin{array}{c}\text { CQA Grade D } \\
\text { AIR SPECIFICATION }\end{array}$ \\
\hline \multicolumn{2}{|c|}{$\begin{array}{l}\text { Oxyoen, Volume \% } \\
\text { Bulance Nitrogen }\end{array}$} & 21.0 & $N / A$ & $19.5-23.5$ \\
\hline \multicolumn{2}{|c|}{ Carbon Monoxide, ppmy } & $<0.2$ & $N / A$ & 10 \\
\hline \multicolumn{2}{|c|}{ Carbon Dioxlde, ppmy } & 101 & $N / A$ & 1000 \\
\hline \multicolumn{2}{|c|}{ Water, ppmy / Dewpoint, of } & $5.6 /-85$ & $N / A$ & $63 /-50$ \\
\hline \multirow{3}{*}{ 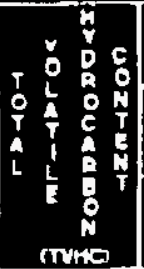 } & TYHC (inoluelng meinonos), PDInY & 6.9 & $N / A$ & $N / A$ \\
\hline & Methone, ppiny & 3.1 & $N / A$ & $N / A$ \\
\hline & TVHC ceroluding meihere', pprny & 3.8 & $N / A$ & $N / A$ \\
\hline \multicolumn{2}{|c|}{$\begin{array}{l}\text { Oll (condeneed), moms } \\
\text { and particulates }\end{array}$} & $N / A$ & $N / A$ & 5 \\
\hline \multicolumn{2}{|c|}{ Odor (provlded by customer) } & None/sllght & $N / A$ & Norie/Slight \\
\hline
\end{tabular}

Thio eample COMPLIES with the gas portion only of CGA Grade D air specifications.

\section{(Note 1) This limit applies to the use of selt conteined breathing apparatus (SCBA) The above limil applies or 10 degrees lower - man the coldest temperature expecied in the area. For non-scBA use the water content may vary with the intended use from T saturated to very dry. \\ E This spceiflcation is tor a PARTIAL sample. l e, elther a source or titter sample was not submitted lur analysis. Nu certificate will be issued since full compllance with the speclication cannot be verified. \\ Laboratory accredited by tha American Assoclation for Laboratory Accreditation (A2LAS.}

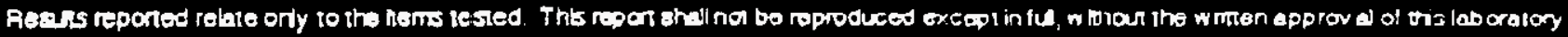

\begin{tabular}{|c|c|c|c|c|c|c|c|}
\hline & Oxyon & Methene & $\begin{array}{l}\text { Carben } \\
\text { Monjoxite }\end{array}$ & $\begin{array}{l}\text { Copon } \\
\text { Dioxito }\end{array}$ & Water & TVHC & $\begin{array}{l}\text { oy } \\
\text { Pen. }\end{array}$ \\
\hline Aceracy (\$) & 99 & 100 & 101 & 100 & 97 & 100 & 100 \\
\hline Prection (\$) & 1.1 & 14 & 1.2 & 2.3 & 0.3 & 11 & 0.6 \\
\hline
\end{tabular}
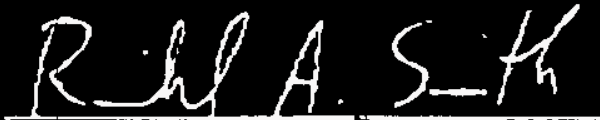

fichard A Smith, C.I.H. - Laboralury Direclo! 


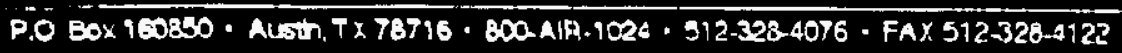

Customere 123

Amerlcan Bristol Ind.

Mr. Chuck Lamoreaux

$1600 \mathrm{~W} 240 \mathrm{th} \mathrm{St}$

Harbor City, CA 90710
Report No.: 94.3848

Date Analyzed: October 27, 1994

Bampled By: K. Lamoreaux

Date Sampled: October 26, 1994

Air Source 1D: L. P. Trailer \#1 SN

1 A9CM22'29RA079112

\section{8ampled for Westinghouse Hanford}

COMPRESSED AIR ANALYTICAL RESULTS

\begin{tabular}{|c|c|c|c|c|}
\hline & $\begin{array}{c}\text { LIMITING } \\
\text { CHARACTERISTIC }\end{array}$ & $\begin{array}{l}\text { SOUACE AR } \\
\text { GESULTS }\end{array}$ & $\begin{array}{l}\text { AMBIENT AIR } \\
\text { RESULTS }\end{array}$ & $\begin{array}{c}\text { CGA Grade D } \\
\text { AIR SPECIFICATION }\end{array}$ \\
\hline $\begin{array}{l}\text { Oxyo } \\
\text { Balan }\end{array}$ & $\begin{array}{l}\text { n. Volume \% } \\
0 \text { Nitrogen }\end{array}$ & 20.9 & N/A & $19.5 \cdot 23.5$ \\
\hline Carbo & Monoxide, ppomr & $<0.2$ & $N / A$ & 10 \\
\hline Carbor & Dioxide, ppmy & 678 & N/A & 1000 \\
\hline Water. & DPmy / Dewpolnt, of & $21.5 / .67$ & N/A & $63 / .50$ nate \\
\hline : & TVHC inotuding mathans', pPInV & 8.1 & N/A & N/A \\
\hline & Methane, ppoir & 3.5 & $N / A$ & N/A \\
\hline 8 & TVHC cevolualing matherese, PPraY & 4.6 & N/A & $N / A$ \\
\hline $\begin{array}{l}\text { Oll } l_{0} \\
\text { and } p \text { : }\end{array}$ & $\begin{array}{l}\text { idensed), ma/mi } \\
\text { iticulatos }\end{array}$ & $N / A$ & $N / A$ & 5 \\
\hline Odor & Provided by customer) & None/Slight & N/A & None/Slight \\
\hline
\end{tabular}

This sample COMPLIES with the gas porion only of CGA Grade D alr specitications.

(Note 1) This IImlt epplies to the use of selt coniaitied breatining apparalus (SCBA). The above limit applies of 10 degrees lower than the coldest temperature expecled in the area. For non-SCBA use the water content may vary with the intended use tron saturated to very dry.

This specificallon Is for a PARTIAL sample. i.e. either a source or filter sample was not submitted for anaiysis No certiticate will be issued since fult compltanse with the specification cennot be verified.

Laboratory nccredited by the American Aseoclation for Laboratory Accreditation (A2L A.

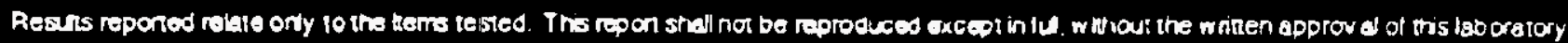

\begin{tabular}{|c|c|c|c|c|c|c|c|c|}
\hline $\begin{array}{c}\text { OC } \\
D\end{array}$ & & Oxycil & Mothene & $\begin{array}{l}\text { Canbon } \\
\text { Monsixide }\end{array}$ & $\begin{array}{l}\text { Conjor } \\
\text { Oloxide }\end{array}$ & Water & TVHC & $\begin{array}{l}\text { on. } \\
\text { Pan }\end{array}$ \\
\hline A & Acarasy (\$) & 89 & 100 & 104 & 100 & 87 & 100 & 100 \\
\hline A & Proction (\%) & 1.1 & 1.4 & 1.2 & 2.5 & 0.3 & 1.1 & 0.6 \\
\hline
\end{tabular}

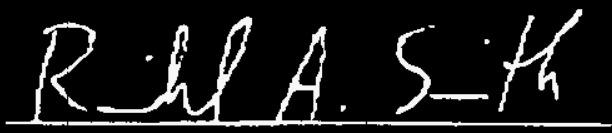

Richard A. Smith. C.I H. - Laboratory Director 


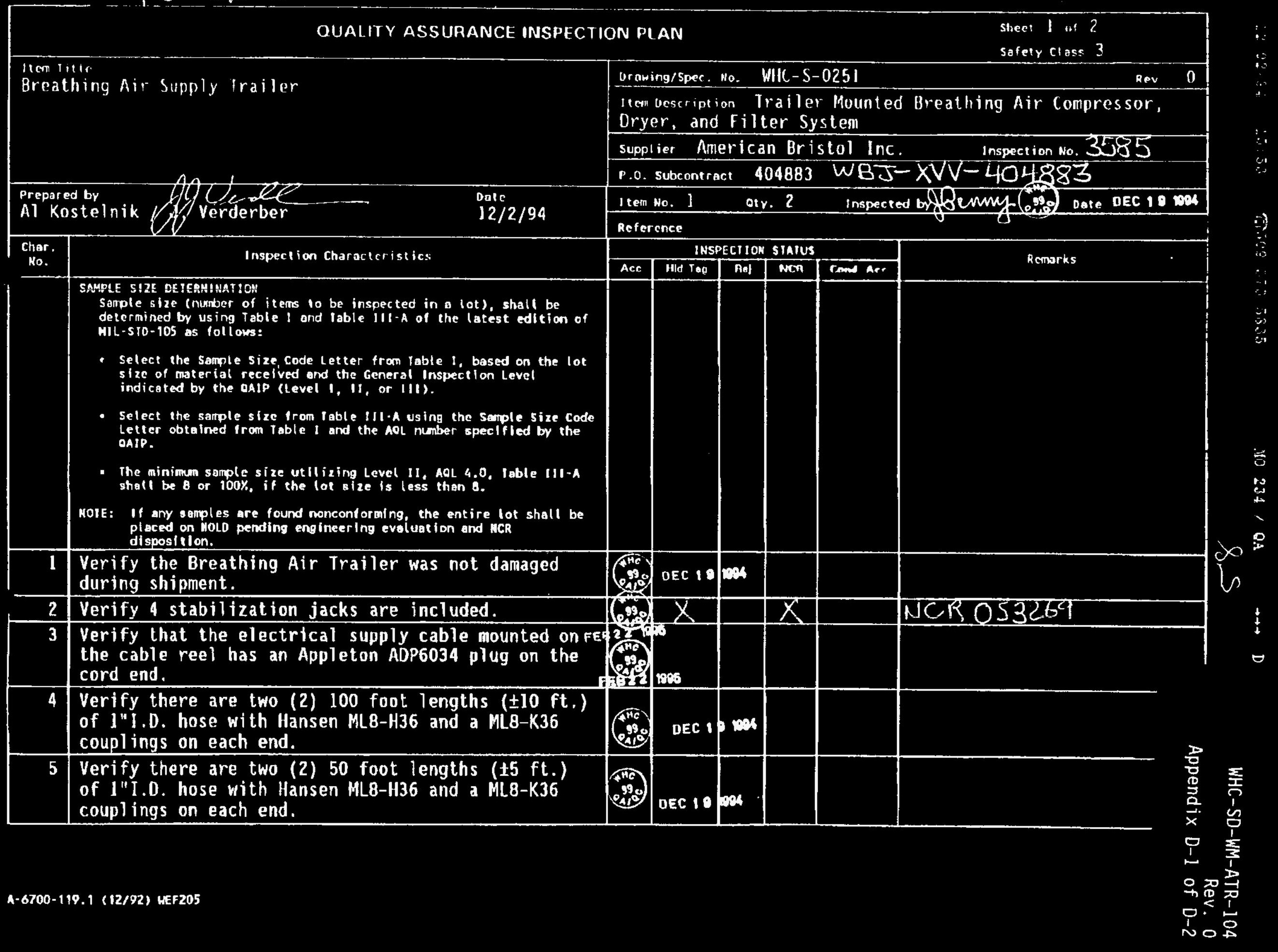




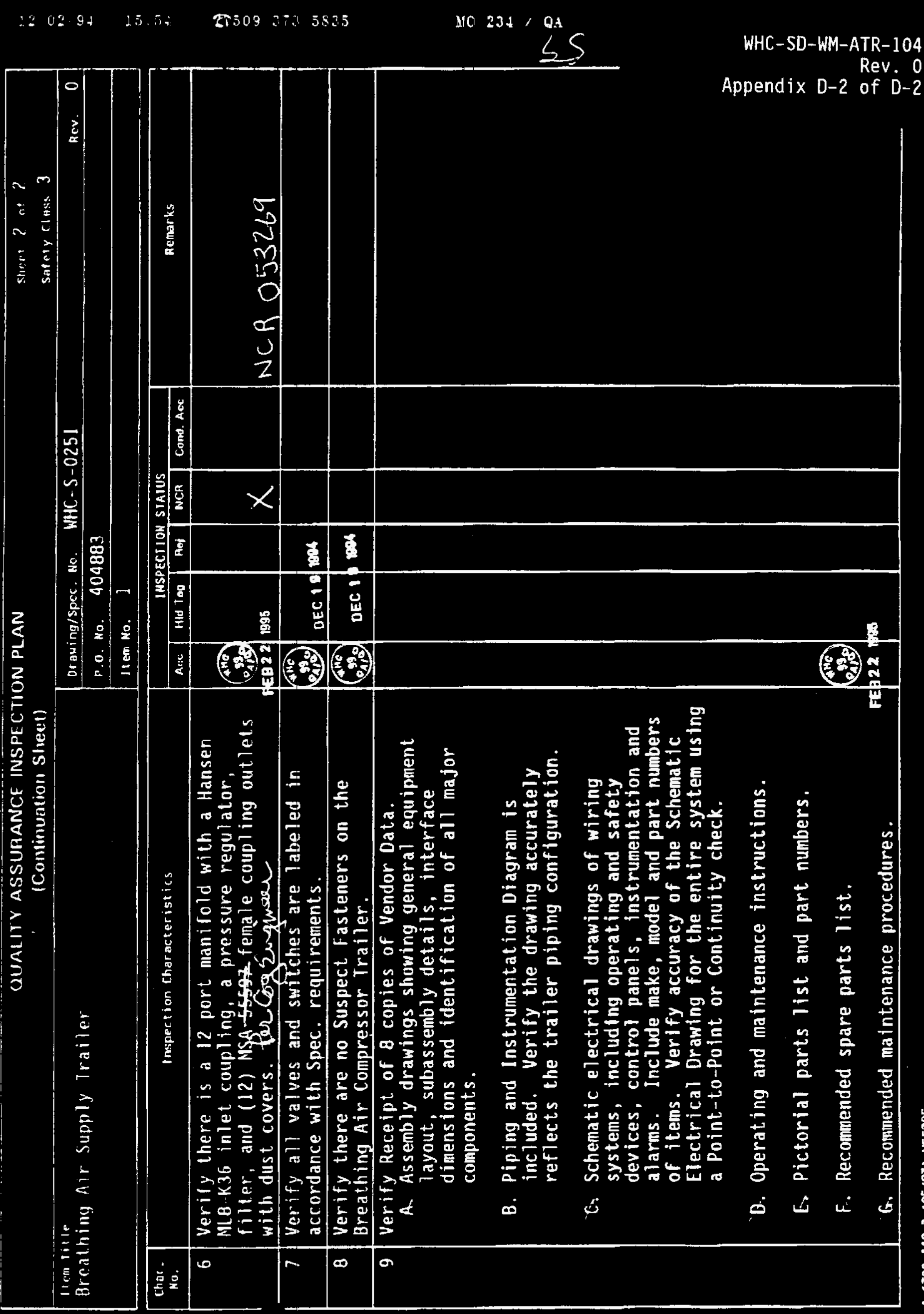

